\title{
NEW INSIGHTS INTO EARLY BRONZE AGE DAMASCENE TECHNIQUE NORTH OF THE ALPS
}

\section{Daniel Berger, Katja Hunger, Sabine Bolliger-Schreyer, Daniel Grolimund, Stefan Hartmann, Jan Hovind, Felix Müller, Eberhard H Lehmann, Peter Vontobel and Marie Wörle}

Daniel Berger, D-06ri8 Halle (Saale), Germany. Email: danielberger.online@gmail.com

Katja Hunger, Swiss National Museum, Collection Centre, CH-89io Affoltern am Albis, Switzerland. Email: khunger79@gmx.de

Sabine Bolliger-Schreyer, Historical Museum Bern, CH-3005 Bern, Switzerland.

Email: sabine.bolliger@bhm.ch

Daniel Grolimund, Paul Scherrer Institute, $\mathrm{CH}-5232$ Villigen, Switzerland.

Email: daniel.grolimund@psi.ch

Stefan Hartmann, Paul Scherrer Institute, CH-5232 Villigen, Switzerland.

Email: Stefan.Hartmann@psi.ch

Jan Hovind, Paul Scherrer Institute, CH-5232 Villigen, Switzerland. Email: jan.hovind@psi.ch

Felix Müller, Historical Museum Bern, CH-3005 Bern, Switzerland. Email: felix.mueller@bhm.ch Eberhard H Lehmann, Paul Scherrer Institute, CH-5232 Villigen, Switzerland.

Email: eberhard.lehmann@psi.ch

Peter Vontobel, Paul Scherrer Institute, CH-5232 Villigen, Switzerland. Email: peter.vontobel@psi.ch Marie Wörle, Swiss National Museum, Collection Centre, CH-89io Affoltern am Albis, Switzerland. Email: Marie.Woerle@snm.admin.ch

Damascening, defined in this context as the inlay of one metal into a different metal base, is a rare decorative technique in the Early Bronze Age, known only from seven bronze artefacts found north of the Alps. This paper reports on the first thorough scientific examination of one such find, the axe from Thun-Renzenbühl grave no. I. This interdisciplinary project involving several institutions in Germany and Switzerland investigated the axe by means of neutron radiographic imaging and X-ray microprobe methods, supported by microscopic examination. The result is an attempt to reconstruct the fabrication and decoration process and to reconsider the enigmatic question of the origins of the damascene technique north of the Alps.

For nearly I60 years the Bronze Age axe from Thun-Renzenbühl was regarded as the earliest and the most impressive metal object to have been made using damascening (metal inlay) north of the Alps. This exceptional object is currently dated to the Early Bronze Age (EBA) A2a period, around I800 BC. ${ }^{\text {I }}$ Until recently there were only two

I. David-Elbiali and Hafner 2010. 
further examples of EBA damascened artefacts from this region, ${ }^{2}$ but three more were added with the discovery in I999 of the so-called Sky Disk and its associated finds from the Mittelberg, near Nebra. ${ }^{3}$ A seventh was subsequently identified during the course of detailed research into the Nebra finds. ${ }^{4}$

The Sky Disk from Nebra, a circular bronze object with a number of inlaid electrum foils representing celestial bodies and other forms, was found together with several other objects within a hoard deposited around I600 BC. However, it is likely that this earliest known representation of the night sky is even older, since the disk has four or five phases of manufacture and use. In Meller's view, the disk might have originated some 200 years before, ${ }^{5}$ in which case it could pre-date the Thun-Renzenbühl axe by some decades, but since its exact dating remains uncertain it is not clear which of these objects is really the earlier. Either way, the Sky Disk and the Thun-Renzenbühl axe represent, along with a small gold-inlaid dagger blade from Priziac, Brittany (I950-I700 BC), ${ }^{6}$ the earliest examples of metal inlay technique outside the Mediterranean world. They are thus crucial to our understanding of the invention and dissemination of damascene technique.

The inlay procedure applied to the Sky Disk is unique in the EBA; it has no parallel in central Europe nor in any other region, ${ }^{7}$ for which reason it is very difficult to relate this singular piece to the other damascened artefacts. By contrast, the damascene technique employed on the axe from Thun-Renzenbühl is directly comparable to other examples from central Europe and the Aegean region; it thus raises the possibility of direct connections between these different cultures, which this study sets out to investigate scientifically.

\section{HISTORICAL BACKGROUND AND DESCRIPTION OF THE AXE}

The axe that is the subject of this paper was found in the Buchholz quarter of the city of Thun, which lies on the north-western coast of Lake Thun, in the centre of the Swiss canton of Bern. The axe is a typical example of a type characterised by fairly low flanges running the full length of the sides. Such objects occur frequently as single finds in hoards and in graves, the latter being the context of this find. It was revealed as part of a rich stone cist burial during commercial gravel digging in December I829 on the southern side of Renzenbühl hill. ${ }^{8}$ The grave belongs to a small cemetery of the EBA Aare Rhône group and is commonly referred to as Thun-Renzenbühl grave no. I. ${ }^{9}$ As well as this exceptional axe, it yielded eleven other metal artefacts typical of EBA period A2a, along with human remains, possibly those of a male (Fig I). ${ }^{\text {IO }}$ Although the find records are confusing, careful analysis of the existing material and comparison with similar burials has led Strahm to suggest a reconstruction of the disposition of objects on and around the body (Fig 2). ${ }^{\text {II }}$ The implication is that the grave inventory belonged to a single - and thus

2. Eluère 1982, 46-7, fig 52.I; Schauer 1984, fig 42.

3. Meller 2002; 2010.

4. Schwab et al 20 Io.

5. Meller 2010.

6. Eluère $1982,46-7$, fig 52.I.

7. Berger et al 2010; Berger 2012a.

8. Lohner 1832.

9. Strahm I968.

I0. David-Elbiali and Hafner 2010, fig 9.

II. Strahm I968; I972. 


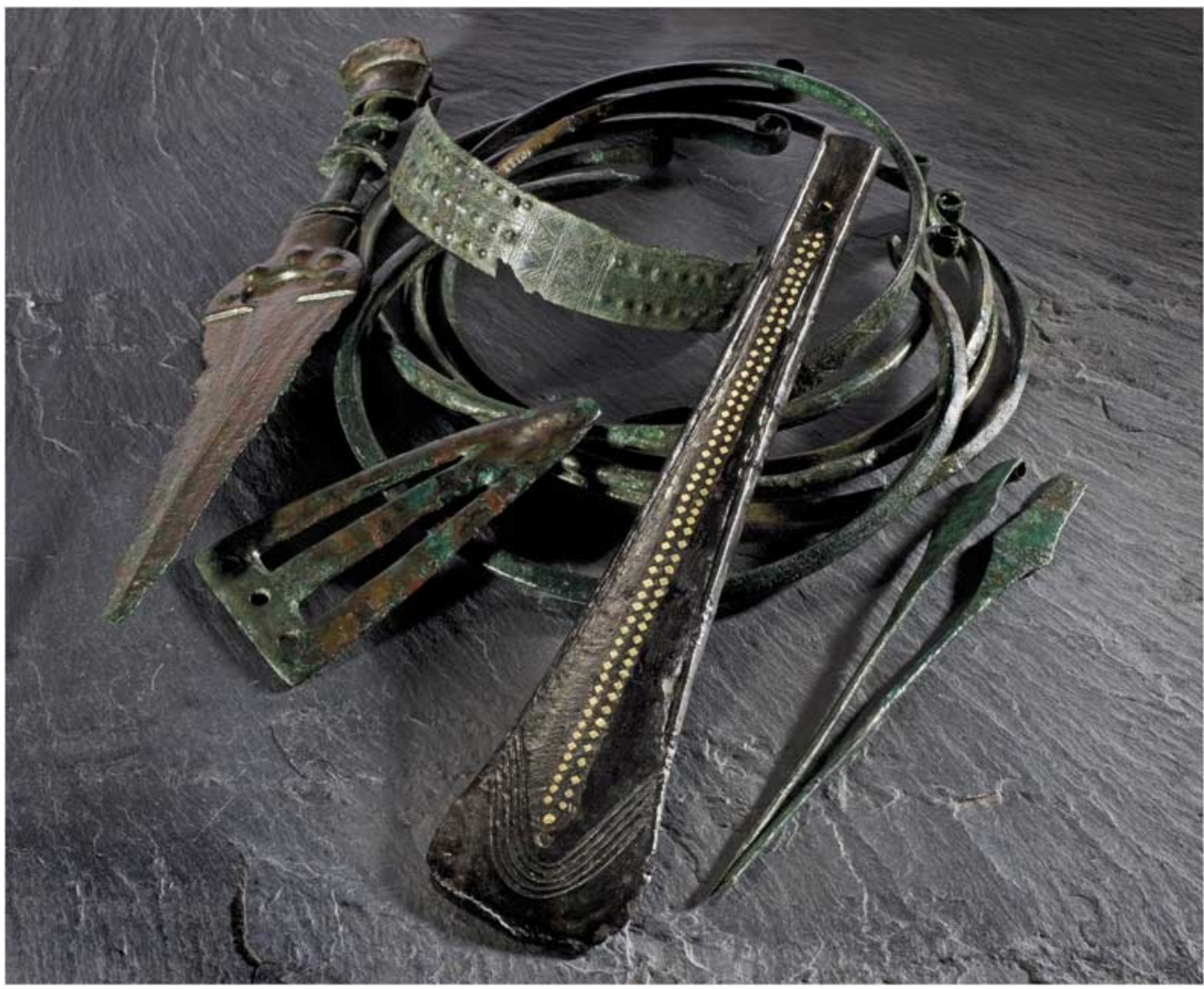

Fig I. The finds from grave no. I in the Renzenbühl cemetery, in the city of Thun (Bernisches Historisches Museum inv. nos I0327-I0328, I033I-I0333, I0336, 10339, I0343, I0346-I0347, I035I, 10353). Photograph: N Frey, Bernisches Historisches Museum

wealthy - person, who must have played an important role in the EBA society of the alpine region around Lake Thun. Nevertheless, his precise status remains speculative.

The elevated social status of the buried male is highlighted above all by the exceptional design of the axe (Fig 3), which probably served as a weapon and/or a status symbol rather than as a tool for felling timber or for woodworking. Apart from its elongated shape, the deeply curved, rather spatulate, cutting edge would not be particularly suited to utilitarian purposes. Such axes are known as Löffelbeile (literally 'spoon-axes') and are mainly found in the western part of Switzerland. ${ }^{\mathrm{I2}}$ The butt end of the long body is missing, and one corner of the broken cutting edge was reattached in modern times. The lower blade has been decorated with a band of deeply curved grooves that would have echoed the line of the cutting edge, an ornament that is paralleled on a couple of contemporary counterparts. ${ }^{13}$

I2. Kibbert 1980.

I3. David-Elbiali 2000, IOI-3. 


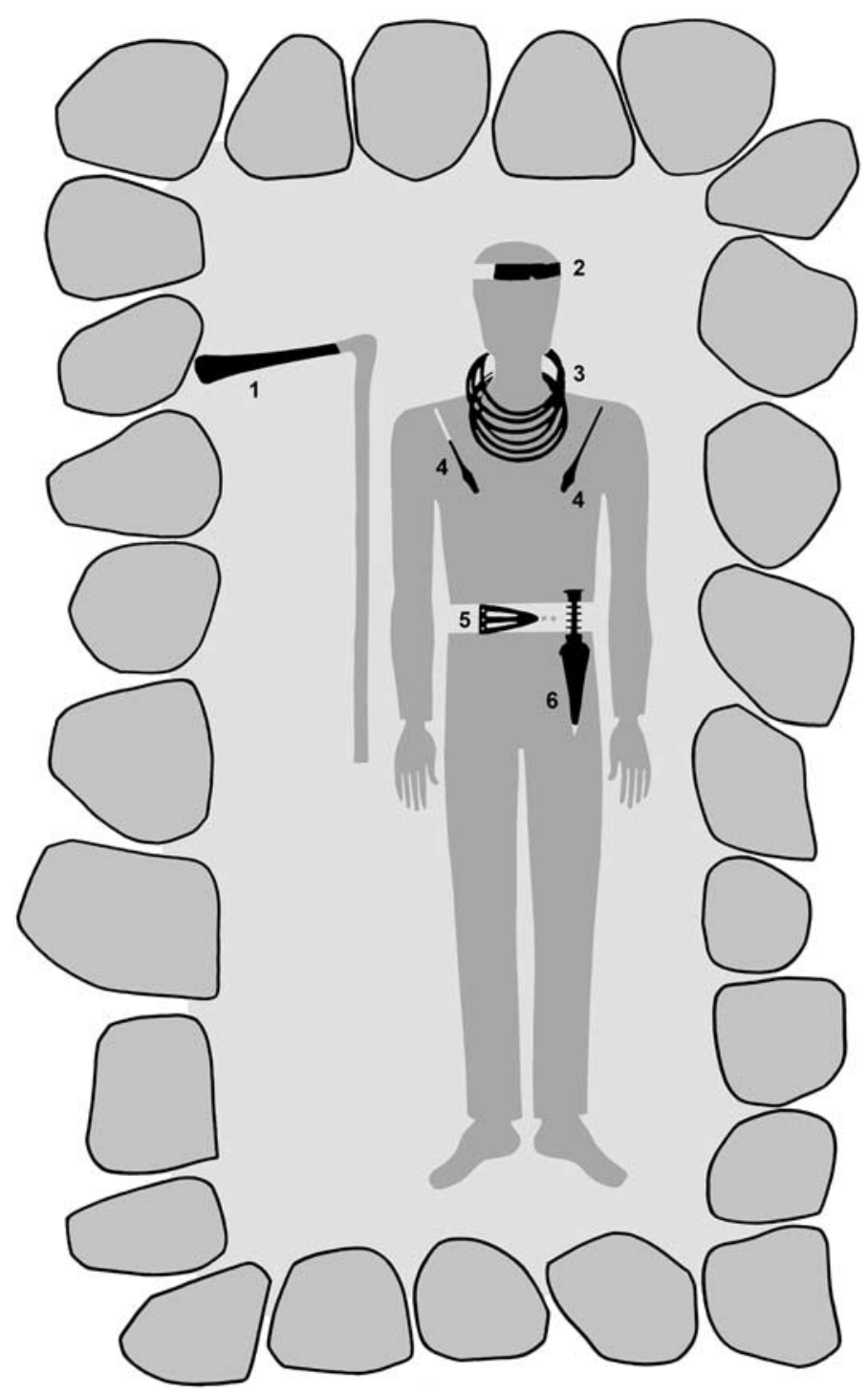

Fig 2. A reconstruction of the east-west-oriented stone cist structure of grave no. I (c 3m in length and $\mathrm{I} .5 \mathrm{~m}$ in width) showing the arrangement of the male body and the grave goods based on descriptions from Lohner (I832) and finds in similar burials. Note that the axe (I) is depicted mounted in a wooden haft; the other bronze artefacts are a diadem (2), six torques (3), two pins with lozenge heads (4), a belt hook (5) and a dagger of Alpine type (6). Drawing: after Strahm 1972, I04

Unique, however, among EBA flanged axes is the striking decoration, which consists of two parallel rows of lozenge-shaped gold inlays running axially down both faces making a total of 198 rhombs (92 on the front and 106 on the back). These rows of rhombs are set within two broad, non-ferrous metal strips, $18 \mathrm{Imm}$ and $186 \mathrm{~mm}$ long, 


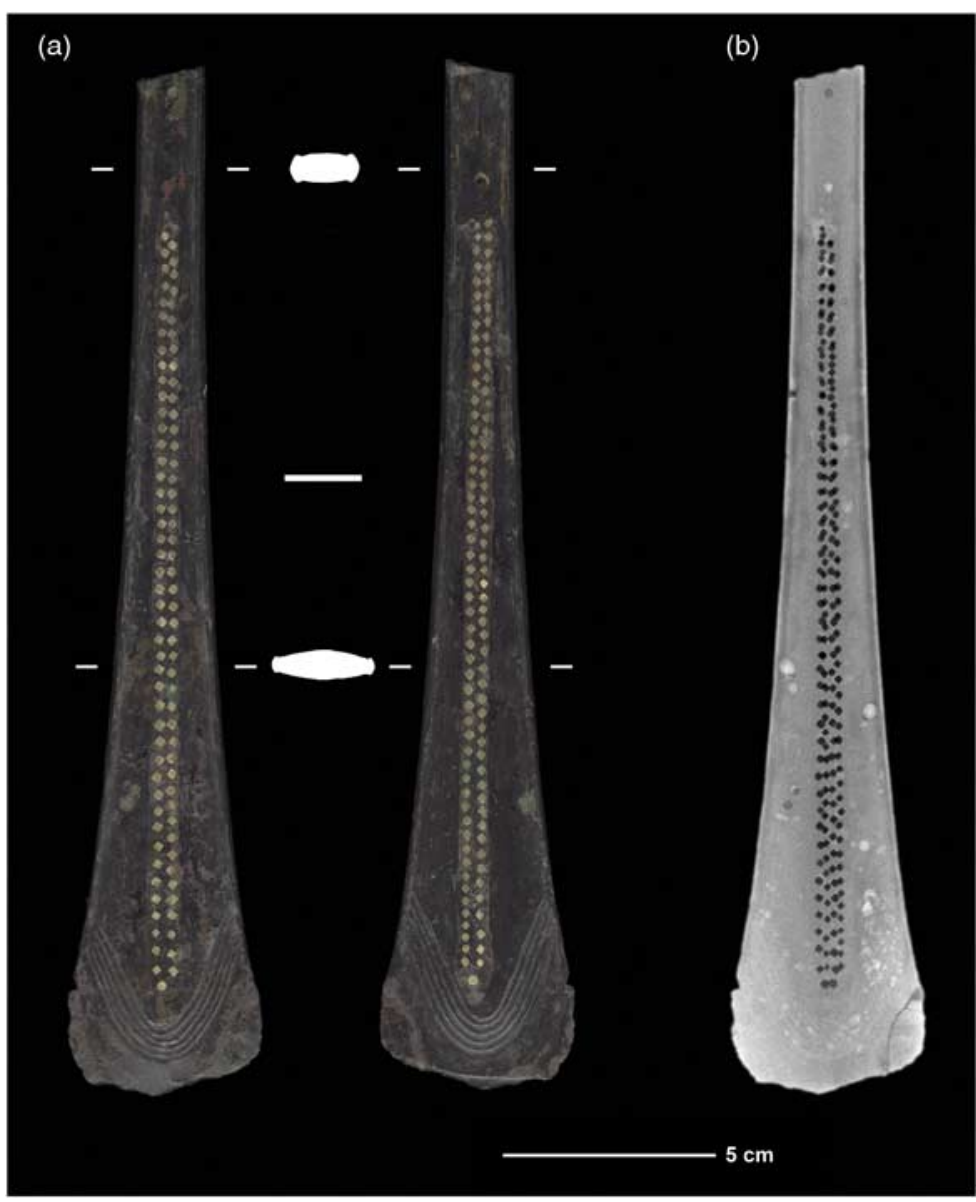

Fig 3. (a) The front (left) and back face (right) of the 24Imm-long axe; (b) a neutron radiography image showing simultaneously the positions of the gold inlays on the front and back faces, showing that they do not match and that the gold does not pass all the way through the body of the axe. Photograph: Daniel Berger

which are themselves set into pre-cut cavities on both faces of the axe (Figs 3 and 4). The combination could best be described as double-damascening. Because of their dotlike appearance, the golden inserts have often been described as gold pins, but this is a misnomer as they do not pass through the axe from face to face (Fig $3 b$ ). ${ }^{14}$ The same applies to one more gold rhomb at one of the flange sides, which is curiously isolated but placed on the midline (Fig 5). Though similar to the other gold inserts, its function as a decorative element is questionable and this single inlay might have been intended to conceal a casting flaw (see Fig I2).

I4. Keller I844, 24; Strahm 1972, 99; Schickler 1974, 723; David-Elbiali and Hafner 2010, 223. 


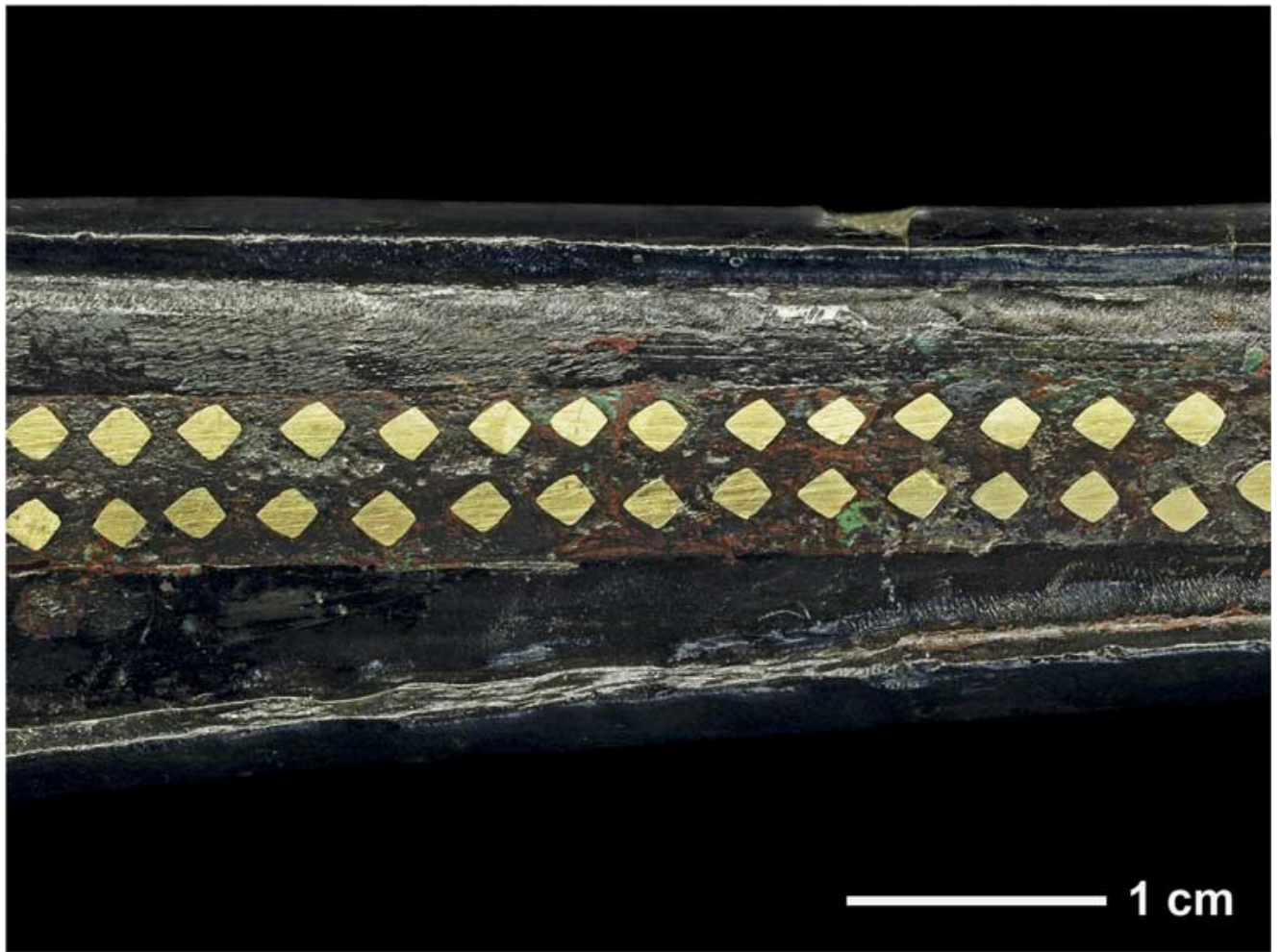

Fig 4. A detail of the double inlay on the back face of the axe; the distinction between the corroded bronze (nearly black in colour) and the corroded copper strip (slightly redder tinge) is clear (though these are not the original colours). Photograph: Daniel Berger

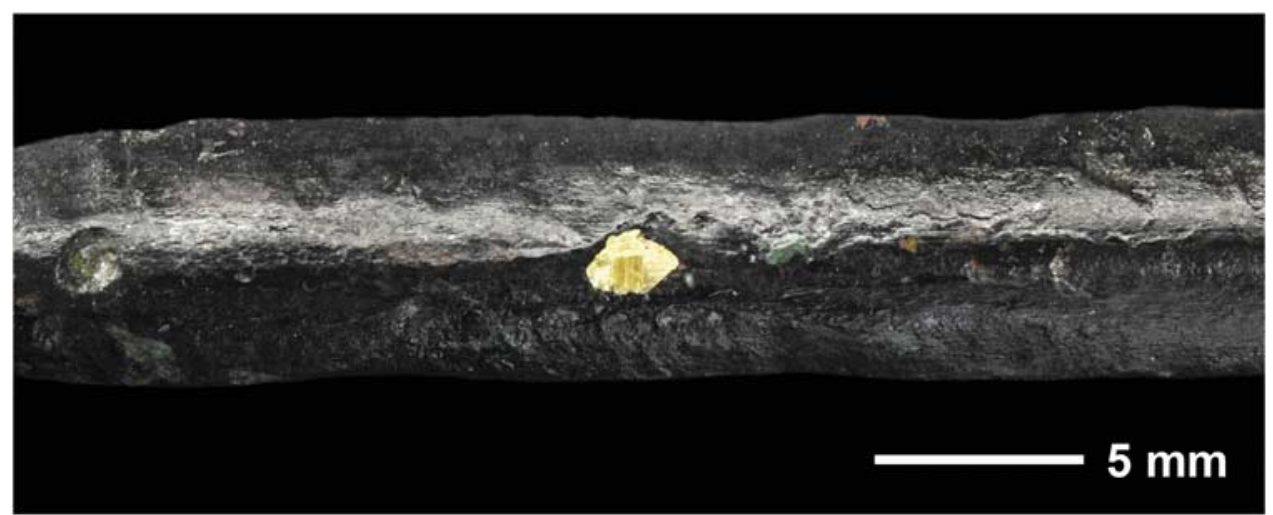

Fig 5. This single piece of gold inlay on the side of the axe has been directly set into the base metal. The difference in the shape of this inlay compared with those in the faces of the axe might result from the difficulty of punching a hole into the bronze base metal or might reflect the shape of a casting flaw that the inlay was intended to fill. There is no corresponding inlay on the opposite flange. Photograph: 


\section{FORMER INVESTIGATIONS AND INTERPRETATIONS}

Thun-Renzenbühl grave no. I has been extensively discussed in archaeological literature. Apart from rather curious astronomical considerations, ${ }^{15}$ previous studies have often sought to ascertain the axe's connections to other cultures and thus the social network responsible for its manufacture. ${ }^{16}$ This has been made more difficult by the lack of comparable double-damascened finds from north of the Alps.

Only a single sword - the 'Marais de Nantes' sword from the area around Nantes, in western France, dating from the sixteenth/fifteenth century $\mathrm{BC}-$ shows a similar kind of decoration, made in this case with copper-joined gold wires (Fig 6d). ${ }^{17}$ Otherwise, only a handful of mostly later objects with slightly simpler damascenings are known to archaeologists. ${ }^{18}$ Amongst these are three sword blades with inlaid copper stripes forming V-shaped ornaments that follow the outline of their cutting edges. Two of them were found within the hoard from Nebra along with the Sky Disk; the third seems to be a single find from the area around Vreta Abbey (Vreta Kloster), in Östergötlands län, Sweden (Figs $6 \mathrm{a}-\mathrm{c}) .{ }^{19}$ All the blades belong to the Sögel type and can be dated to around I600 BC (which gives the latest possible date for the Sky Disk). As a special feature the two pieces from Nebra are combined with the halves of metallic handles that have also been damascened with wires of unalloyed copper. This list is completed by the small damascened dagger blade from Priziac, Brittany, France, ${ }^{20}$ which may be even older than the Thun axe and the Sky Disk, though it has a much simpler decoration, with round, through-passing gold inlays (Fig 7).

In addition to the few damascened examples, there is a series of daggers from Brittany and southern Britain that have organic handles or scabbards with hundreds of tiny gold studs. ${ }^{2 \mathrm{I}}$ These objects are as old as the dagger from Priziac and were inlaid using a technique comparable to damascening, except that the gold is inlaid into antler, wood or leather, rather than metal, and the studs were fixed using some kind of adhesive (resin or animal glue) that is never found in true EBA damascenings. ${ }^{22}$ Nevertheless, they represent the same desire for colour contrast that is found in the case of damascened artefacts.

By contrast with central and western Europe, there is a much larger corpus of metalinlaid and double-damascened objects from the eastern Mediterranean, and especially from the Greek mainland. Several Late Helladic daggers from the Mycenaean culture have perfectly worked inlays of figurative, floral and ornamental motifs that - just as on the Swiss axe - were hammered into broad strips, themselves inlaid into slots in the faces of the dagger (Fig 8). ${ }^{23}$ This use of double-damascening in the case of the Thun axe and the Mycenaean weapons has been cited repeatedly as evidence for a close connection between the two areas and for some kind of technology transfer. ${ }^{24}$ Some researchers have

\footnotetext{
I5. Kerner 2007.

I6. Strahm I972; Schauer I984.

I7. Schauer I984; Briard I984, 90; Berger forthcoming.

I8. Berger 20I2a, cat. no. I ( $\mathrm{pl} \mathrm{I}$ ).

19. Schwab et al 20I0; Berger 20I2a, cat. nos 2-4, 7 (pls 2-4, 7).

20. Eluère I982, 46-7, fig 52.I; Briard I984, 90, 295; Berger 2012a, cat. no. 59.

2 I. Gerloff I975, 88; Eluère I982, 45-7; Clarke et al I985, I37-40; Needham et al 20 Iо.

22. Briard I984, 89-90; Wiltshire Heritage Museum 2008, 7.

23. Xenaki-Sakellariou and Chatziliou I989; Giumlía-Mair and Craddock I993.

24. Reinecke I902; Strahm 1972; Gerloff I975, I I7; Schauer I984.
} 


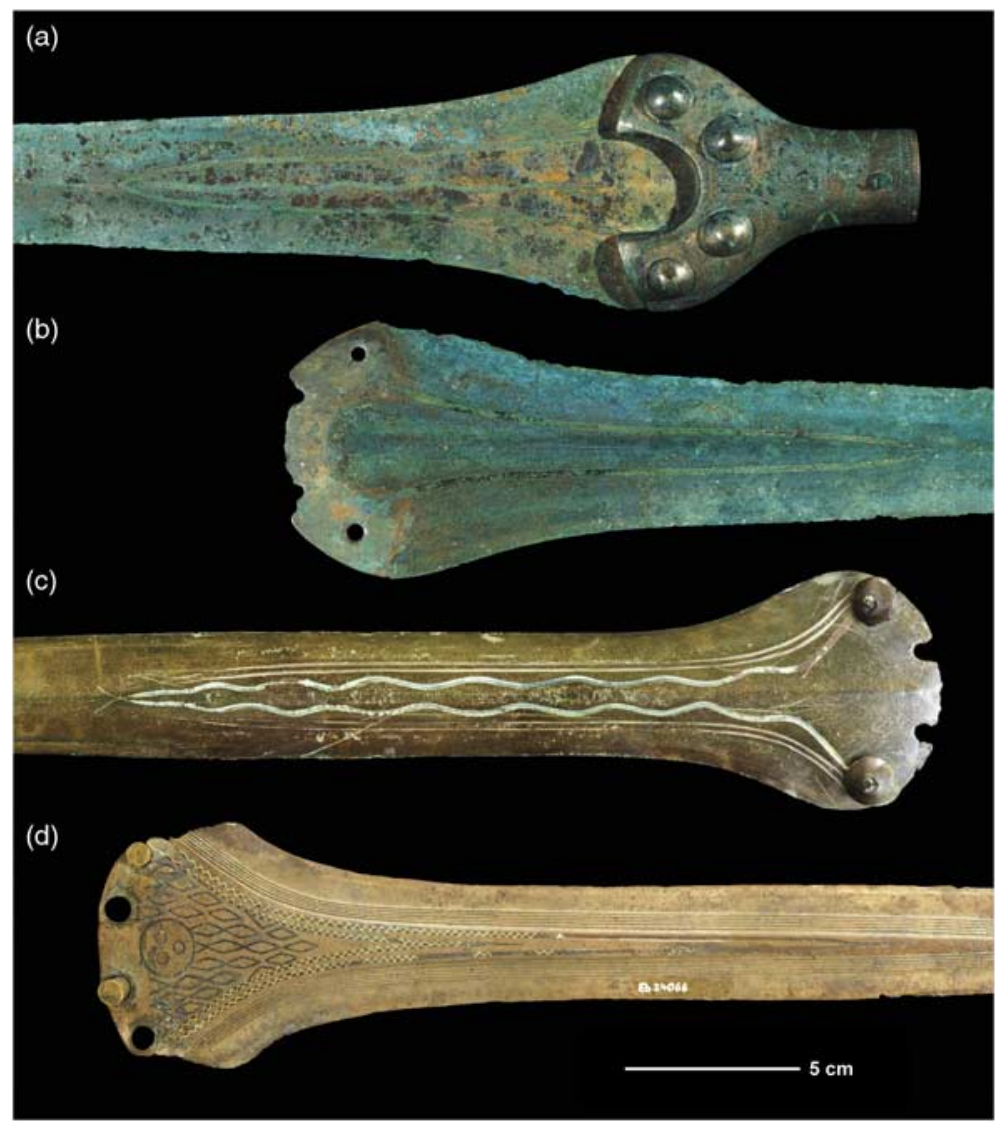

Fig 6. Four Early Bronze Age copper-damascened sword blades: (a) and (b) from Nebra, Germany (State Museum of Prehistory, Halle); (c) from Vreta Kloster, Sweden (Historiska Museet, Stockholm); (d) from 'Marais de Nantes' (Museum zu Allerheiligen, Schaffhausen). The latter is said to date from the sixteenth/fifteenth century BC and has double-damascened strips of copper and gold in a base of a lowtin bronze, comparable to those on the Thun-Renzenbühl axe. Photographs: Daniel Berger ( $a$ and b); Christian-Heinrich Wunderlich (c and d)

actually postulated that the damascene technique originated in the Aegean. ${ }^{25}$ Others have pointed out that the Greek damascened artefacts are all more recent in date than the axe and so cannot be precursors. ${ }^{26}$ To resolve this conundrum, Strahm proposed a common derivation from older artefacts from somewhere in the northern part of the Balkan peninsula, ${ }^{27}$ whereas Jung recently envisaged that Italian EBA cultures played an intermediate role between the Aegean and Swiss regions. In this context Jung refers to three Levantine double-damascened scimitars from Byblos, in Syria, and Balâța-Sichem, in Palestine, which

25. Eg, Meller 2004; Wunderlich 2005; Berger et al 2010.

26. Jung 2010, 667-8.

27. Strahm 1972, 108. 


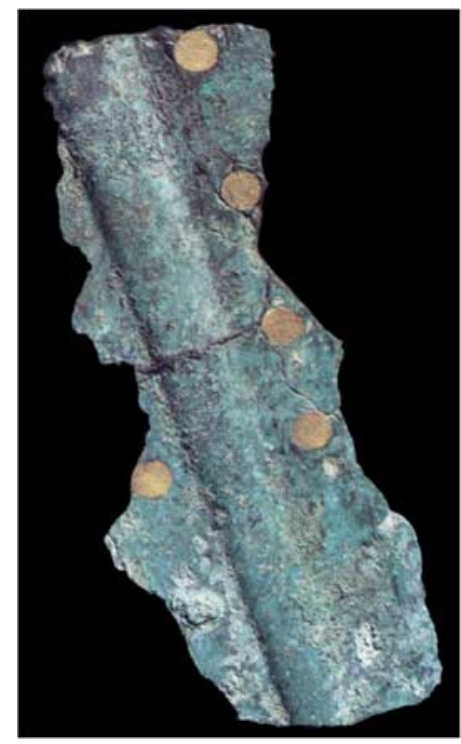

Fig 7. The dagger blade fragment from Priziac, Brittany, France with five surviving gold roundels inlaid into the non-ferrous metal base. Overall, there were probably eight such gold inlays. Length $97 \mathrm{~mm}$. Laboratoire d'Anthropologie, Université de Rennes. Photograph: after Clarke et al I985, fig 4.74

for a long time were dated to the end of the nineteenth century BC. Recent opinion, however, favours a seventeenth-century $\mathrm{BC}$ date for these objects, so presumably they can no longer be considered precursors of the Thun axe either. ${ }^{28}$ Jung's idea had already been contemplated by Tschumi, ${ }^{29}$ but neither he nor the other writers have been able to cite actual damascened or related artefacts from the regions in question to support their theories.

For further light on this question, researchers have turned to archaeometallurgical analysis. This showed that the Thun gold inlays have a similar chemical composition to many objects from both the Danube and Aegean regions. ${ }^{30}$ On this basis Hartmann drew the tentative conclusion that the gold on the axe was probably acquired through trade between central and south-eastern Europe. ${ }^{3 \mathrm{I}}$ Unfortunately, although spectroscopic analyses have been conducted on the bronze body of the axe, showing it to be a tin bronze, the trace element pattern revealed cannot be linked to a specific ore deposit. ${ }^{32}$ Indeed, the gold analyses undertaken by Hartmann were also very limited by comparison with what is analytically possible today. ${ }^{33}$ Thus the question of whether the application of the damascene technique on the axe from Thun-Renzenbühl was an indigenous invention of the Aare Rhône group or whether it reached the area north of the Alps through

28. Jung 2010, 666-8.

29. Tschumi 1942 .

30. Hartmann I982, no. Au I76r.

3I. Ibid, 35 .

32. Flatt and Huber 1942; Junghans et al 1968, no. 2853.

33. By determining the geochemical trace element pattern with modern analytical methods, Ehser et al 20I I were able to track down the origin of the Sky Disk gold (electrum) to secondary ore deposits in south-western Britain. 


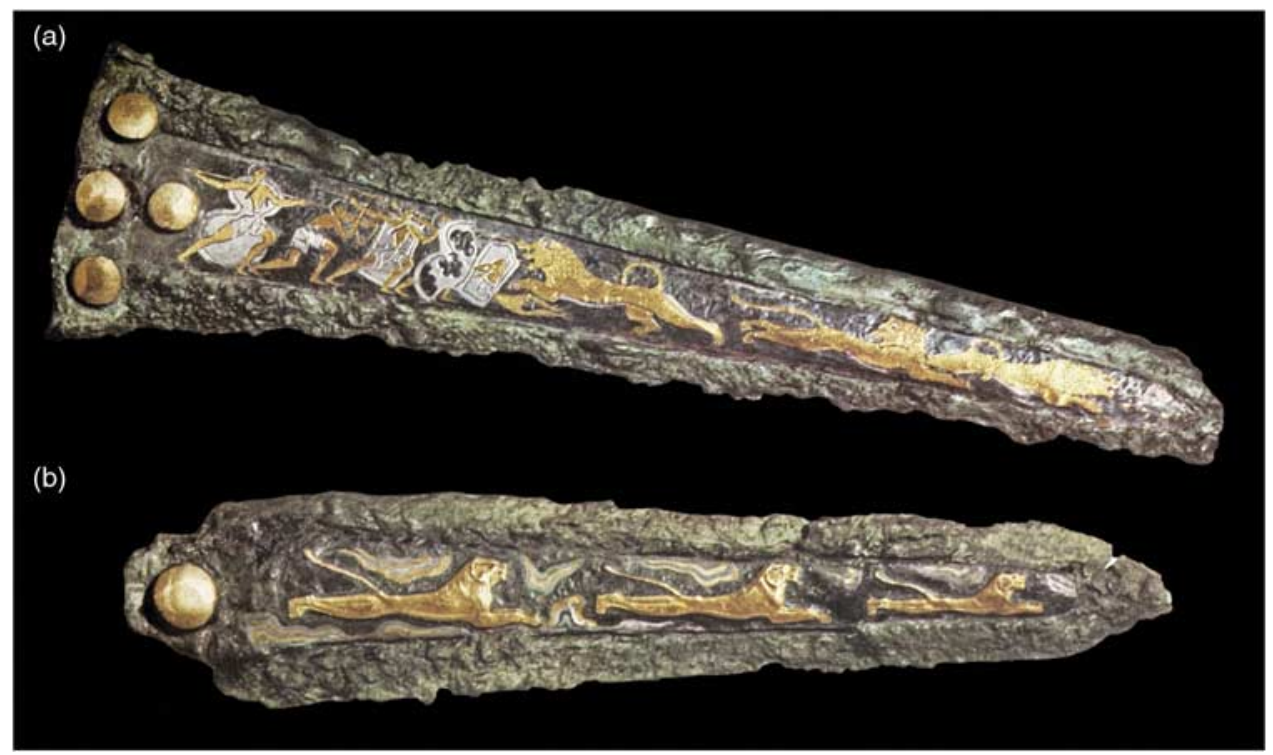

Fig 8. Two examples of damascened daggers from shaft burials at Mycenae, grave circle A. Both are decorated with double and triple damascenings depicting hunting scenes and running lions. Additionally, the rivets are gold-plated. (a) measures $238 \mathrm{~mm}$ and (b) $214 \mathrm{~mm}$ in length. National Archaeological Museum, Athens, inv. nos 394 and 765. Photograph: after Giumlía-Mair and Craddock 1993, fig 29

technological transfer remained unresolved, along with its relationship to other central European damascened objects.

Our aim was to see whether detailed examination of the inlay decoration itself might have a significant bearing on connections between the known artefacts, and thus also on the roots of the metal inlay technique. Hence a primary aim of this study was to investigate the processes involved in the manufacture and decoration of the axe and to evaluate the results against the background of the other objects. In addition new analyses of the different metal parts were undertaken. This was particularly important for the copper-base inlay strips, which had not previously been analysed.

\section{THE EXPERIMENTAL PROCEDURE}

In view of the artefact's uniqueness it was necessary to apply analytical methods that were completely non-destructive. After a first inspection using optical microscopy, neutron tomography was applied, rotating the object in 375 steps around 360 degrees. This allowed both the outline and interior structure of the axe to be visualised in a full threedimensional reconstruction. The scanning was performed at the thermal neutron radiography beamline NEUTRA of the spallation neutron source SINQ of the Paul Scherrer Institute (PSI), Switzerland, ${ }^{34}$ during which the artefact had to be fixed in an aluminium

34. See the website of NIAG - Neutron Imaging and Activation Group:〈http://www.psi.ch/niag/ (2I Nov 20I2). 


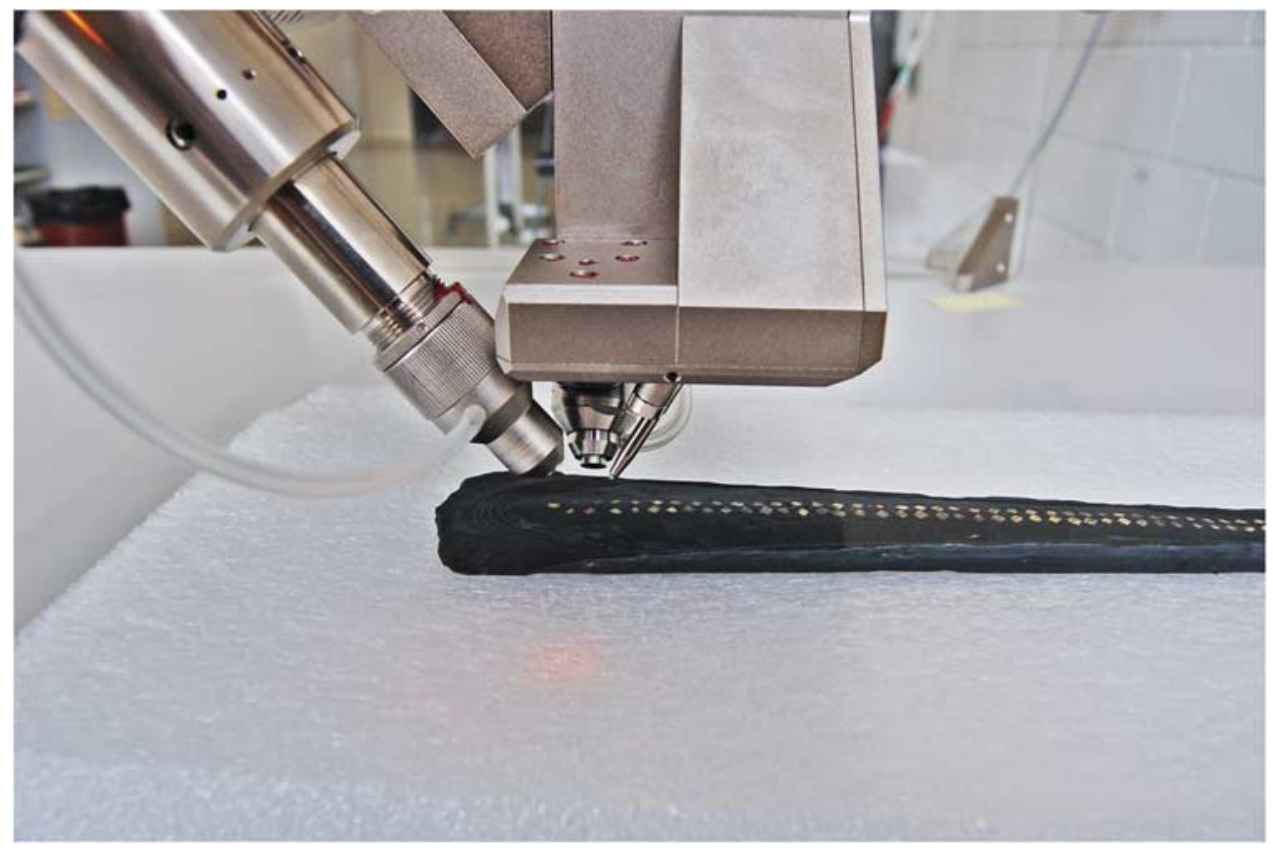

Fig 9. Experimental set-up of the micro-XRF analysis using the ARTAX 800 system. Photograph: Katja Hunger

vessel wrapped in aluminium foil. Owing to this experimental set-up a relatively poor spatial resolution of only $250 \mu \mathrm{m}$ could be achieved. ${ }^{35}$ This has imposed limitations on our structural interpretation and the volume rendering of single object parts.

In addition to visualisation, the axe was investigated by micro-X-ray fluorescence analysis (micro-XRF) carried out at the Collections Centre of the Swiss National Museum and at the micro-XAS beamline (XosLA) of the Swiss Light Source (SLS) of the PSI. The latter institution used a synchrotron-based set-up, whereas the former worked with conventional XRF micro-spectrometers to clarify the metal composition of the axe's body and the inlaid parts. Because the whole axe is covered with some kind of organic protection layer, which badly scattered the rhodium radiation from the X-ray sources employed, two different XRF spectrometers (ARTAX 800 and Eagle III XXL) had to be applied at the Swiss National Museum. ${ }^{36}$ The rhodium radiation $\left(\mathrm{Rh}-\mathrm{L}_{\beta}\right)$ overlapped with the silver lines $\left(\mathrm{Ag}-\mathrm{L}_{\alpha}\right)$ in the spectrum of the golden inlays; this could be eliminated only by employing an aluminium filter in connection with the ARTAX 800 microspectrometer

35. Experimental set-up of neutron tomography: Andor camera DV434 (I024 × I024 CCD chip), Ioo $\mu \mathrm{m}$ thick $\mathrm{Li}-6$ doped $\mathrm{ZnS}$ screen (for converting neutron radiation to visible light), scan of two sections, OCTOPUS and VG Studio software. For detailed set-up information see Grolimund et al $201 \mathrm{I}$.

36. The organic covering derives from conservation at the Römisch-Germanisches Zentralmuseum Mainz, undertaken in 1963. Prior to this a large part of the corrosion crust had been removed from the cutting edge, resulting in modern scratches in this region. 


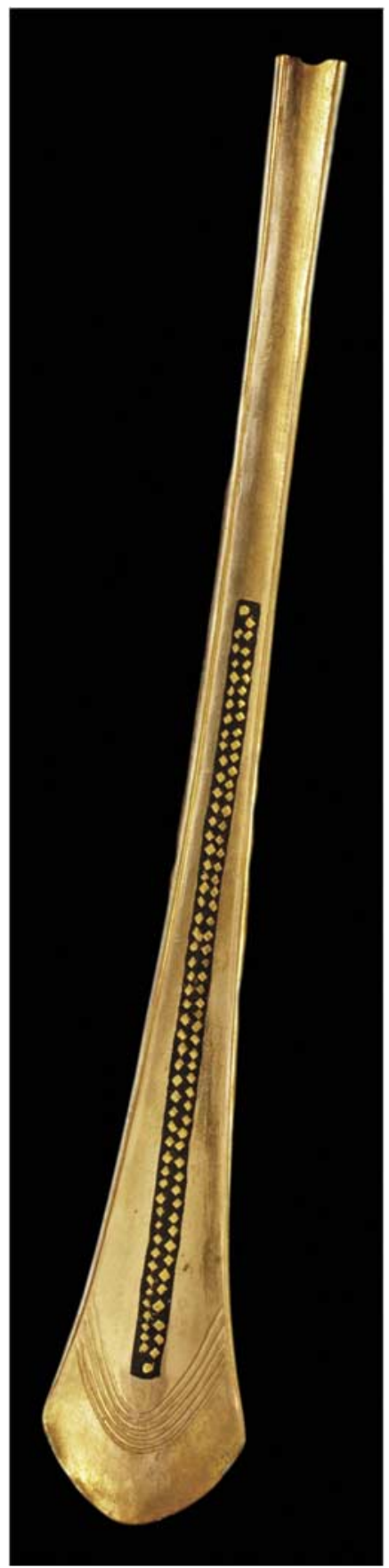

Fig IO. Reconstruction of the axe to the colours as perhaps originally intended. The gold-coloured base metal and inlays contrast with the black-patinated copper strip. This presupposes deliberate treatment of the copper to alter its colour, perhaps with the patination method investigated by D Berger (Berger 20I2a). Photograph: Swiss National Museum, Zurich 
(Bruker AXS) (Fig 9). ${ }^{37}$ In contrast, the Eagle III XXL system (Roentgenanalytik Systeme $\mathrm{GmbH} \& \mathrm{Co}$. KG) works in a vacuum and was thus the first choice for analysing the copper-based parts. ${ }^{38}$ In order to obtain results that were as closely representative of the metals as possible, the least corroded areas of the surface were chosen for analysis.

Like the laboratory-scale X-ray analysis, the synchrotron-based investigation at the PSI gives information on the elemental composition of the object's surface, albeit with better spatial resolution. Moreover, the experimental set-up allowed a mapping of the elemental distribution. The same system was used simultaneously in reflection mode to get distinct diffraction patterns of the patinas from the different metal parts. This was done in the hope of obtaining information about potential artificial patination procedures - since the different components would have rather similar colours in their original metallic states, it seems entirely likely that some sort of treatment could have been applied to highlight the differentiation (Fig IO). It has to be noted, however, that microdiffraction imaging of large and bulk objects in reflection geometry with synchrotron sources is by no means a standard or well-established analytical approach. The present investigation of the axe has a pioneering character and various challenges regarding the data acquisition methods, processing and interpretation are unresolved. ${ }^{39}$

\section{THE RESULTS FROM METAL ANALYSES}

Earlier analyses of drilled samples from the axe showed that the base material consists of an ordinary tin bronze containing around rowt $\%$ tin along with some natural impurities. ${ }^{40}$ The $\mathrm{XRF}$ and diffraction analyses carried out here support this result but without being able to provide definite numerical values, because of the corroded state of the surface. However, the metal strip inlays proved to be quite free from tin and consequently consist of nearly pure copper, unlike the body of the axe (Fig II). The impurities detected amounted to less than I per cent and can be explained as incorporated soil elements (iron, chlorine, aluminium, sulphur, silicon, calcium) and elements derived from the copper ore (nickel, arsenic, silver). In addition it is possible to rule out any deliberate addition of gold or silver to the copper, such as has been observed on several Mycenaean and Levantine damascened objects. ${ }^{4 \mathrm{I}}$ This difference will be important in reviewing possible cultural connections below.

Although it was only possible to reanalyse the gold rhombs non-destructively at the surface, this had the virtue of allowing all I99 pieces to be investigated with the ARTAX 800 system. Hence we now have information on the whole set of inserts, in contrast to earlier studies. Our results show a relatively consistent composition, with all the rhombs containing between $28.4 \pm 0.5 \mathrm{wt} \%$ and $30.3 \pm 0.5 \mathrm{wt} \%$ silver and approximately $\mathrm{I} \pm 0 . \mathrm{Iwt} \%$ copper with gold as the main constituent. The inserts thus appear to be composed of electrum, a naturally occurring alloy of gold and silver. ${ }^{42}$ Apart from the small tin content,

37. Analysing parameters of ARTAX 800: $50 \mathrm{kV} / 600 \mu \mathrm{A} / 60 \mathrm{~s}$, Rh tube, Al filter ( $3 \mathrm{I} 5 \mu \mathrm{m})$, $50 \mu \mathrm{m}$ capillary tube, SD detector, quantitative analysis with reference material in air.

38. Analysing parameters of Eagle III XXL: $20 \mathrm{kV} / \mathrm{I} 00 \mu \mathrm{A} / 200 \mathrm{~s}$, Rh tube, Rh filter, $50 \mu \mathrm{m}$ capillary tube, $\mathrm{Si}(\mathrm{Li})$ detector, vacuum, quantitative analysis with reference material.

39. Grolimund et al $201 \mathrm{I}$.

40. Junghans et al 1968, no. 2853.

4I. Giumlía-Mair and Craddock 1993; Ogden 1993; Giumlía-Mair 1996; Giumlía-Mair and Riederer 1998.

42. The copper content is probably slightly higher than specified as there was partial overlap between the characteristic copper and gold radiations that influenced the quantification. 

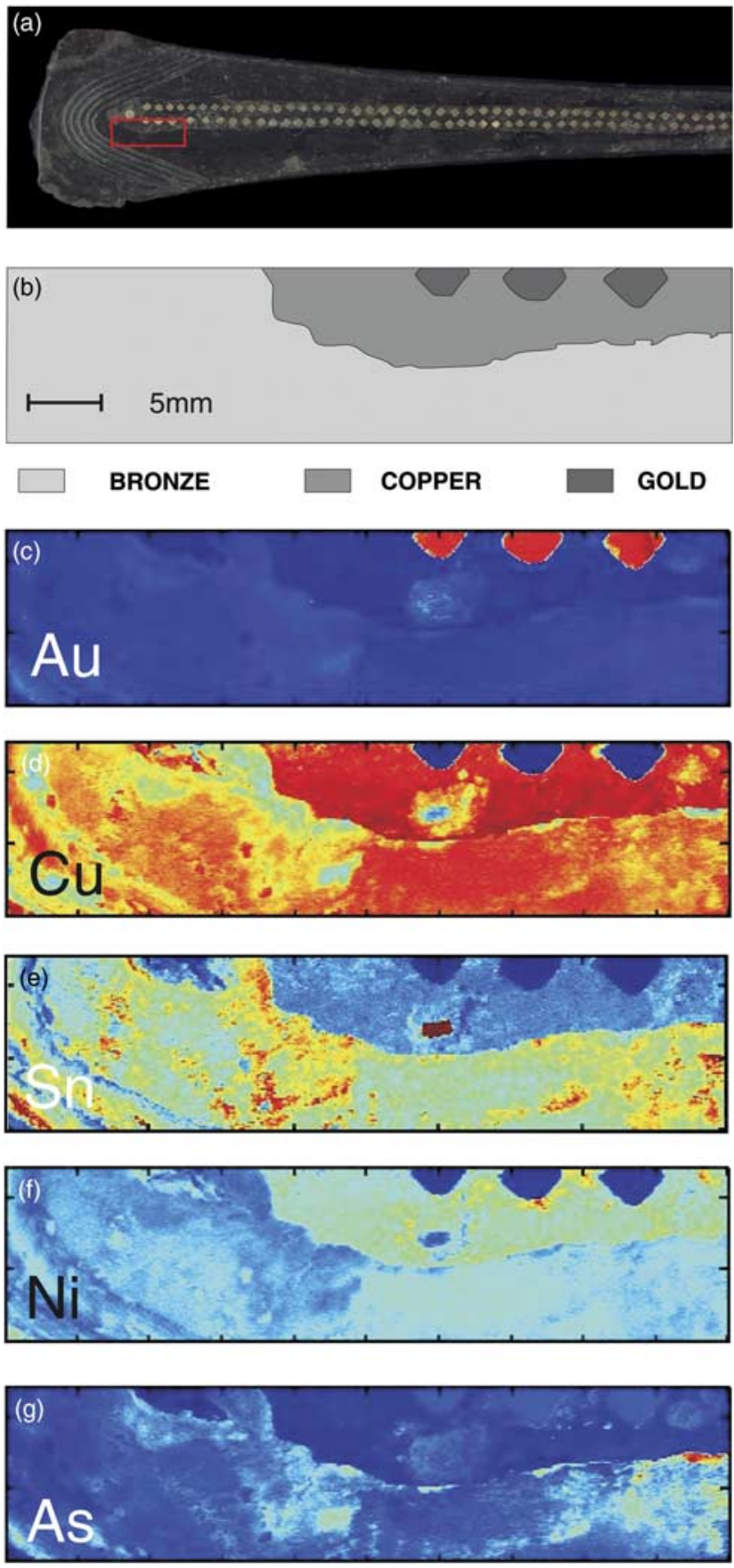

Fig II. Elemental distribution maps covering the three different metal parts of the axe (bronze body, copper inlay and gold inlays): (a) overview of axe showing the location of the area subjected to chemical imaging; (b) schematic representation of the sample area; (c)-(g) maps for element: (c) gold ( $\mathrm{Au})$; (d) copper $(\mathrm{Cu})$; (e) tin $(\mathrm{Sn})$; (f) nickel (Ni); (g) arsenic (As). Images: Daniel Grolimund 
this agrees with the older analyses of Flatt, Huber and Hartmann; ${ }^{43}$ what is new is that we now know that every rhomb-shaped insert derives from the same precious-metal batch and from the same ore deposit. On this evidence it is possible to conclude that the insertion of the electrum inlays (including the single one at the flange) was almost certainly achieved as a single operation.

\section{THE RESULTS FROM NEUTRON TOMOGRAPHY}

The neutron tomography investigation provides a completely new insight into the interior of the axe with the result that the sequence of manufacture - the chaine operatoire - can be deduced. Virtual sections in all three directions (examples of which are shown in Fig I2) clearly illustrate the very porous structure of the bronze throughout the axe. The biggest accumulation of casting voids is found in the blade region, whereas the calculated numerical values of the void volumes show that the largest holes concentrate in the haft end (Fig I3a). These observations indicate that the mould was upright with the haft end upwards, allowing gas to coalesce to bigger pores during casting. The sprue (the passage through which the molten metal was introduced into the mould) would thus have been at the butt end of the object, as $M$ Wirth has already suggested for EBA flanged axes as a whole. ${ }^{44}$ The abnormally high degree of porosity, which, in view of its rounded structure, largely corresponds to gas inclusions, could be caused by insufficient degassing or heating of the bronze melt, or by a discharge of residual water from the mould material. The latter possibility points to the use of a lost-wax casting mould or a two-piece clay mould. Both types of mould would, in fact, provide the easiest ways of creating the nearly $3 \mathrm{~mm}$-deep and $7 \mathrm{~mm}$-wide channels for the copper-strip inlays. ${ }^{45}$ If this conclusion is correct, the Thun axe would differ significantly from other EBA flanged axes, which were normally cast in two-piece stone moulds. ${ }^{46}$

Further clues are gleaned from the shape of the gas voids. Because they are still well rounded and not elliptical it is very unlikely that the bronze surface saw much forging after the axe was cast (Figs I2 and I3b). However, there are faint deformations in the region of the flanges (Figs I2.3, I2.6) and the blade (Fig I2.I). The former might be an indication that the flanges have been worked up or enhanced afterwards; this probability is reinforced by subtle traces of hammering or punching alongside the edge (see Fig 4 ). ${ }^{47}$ The deformation that is visible on voids at the blade can be accounted for, at least partly, by the chasing of the curved grooves.

Because the linear attenuation coefficient for neutrons is nearly the same for copper and for bronze these two metals cannot be distinguished on the neutron tomography images, but the gold inlays and the voids show as areas of different brightness. ${ }^{48}$ Nevertheless, it is easy to see that there is no gas porosity in the copper inlays, by contrast

43. Flatt and Huber 1942; Hartmann 1982, no. I761.

44. Wirth 2003, 4I-62, I29-30.

45. Because, first, such grooves cannot be achieved by using bronze chisels and, second, it is difficult to provide the negative of the channels on stone moulds.

46. Billig 1957, 296; Hundt I973, 208.

47. The possibility cannot be excluded that the flanges already existed on the wax or wooden model to some extent.

48. The linear attenuation coefficient for thermal neutrons in copper and bronze is $\approx \mathrm{Icm}^{-\mathrm{I}}$, in gold $\approx 6 \mathrm{~cm}^{-1}$ and in air $7 \cdot 10^{-5} \mathrm{~cm}^{-1}$. 


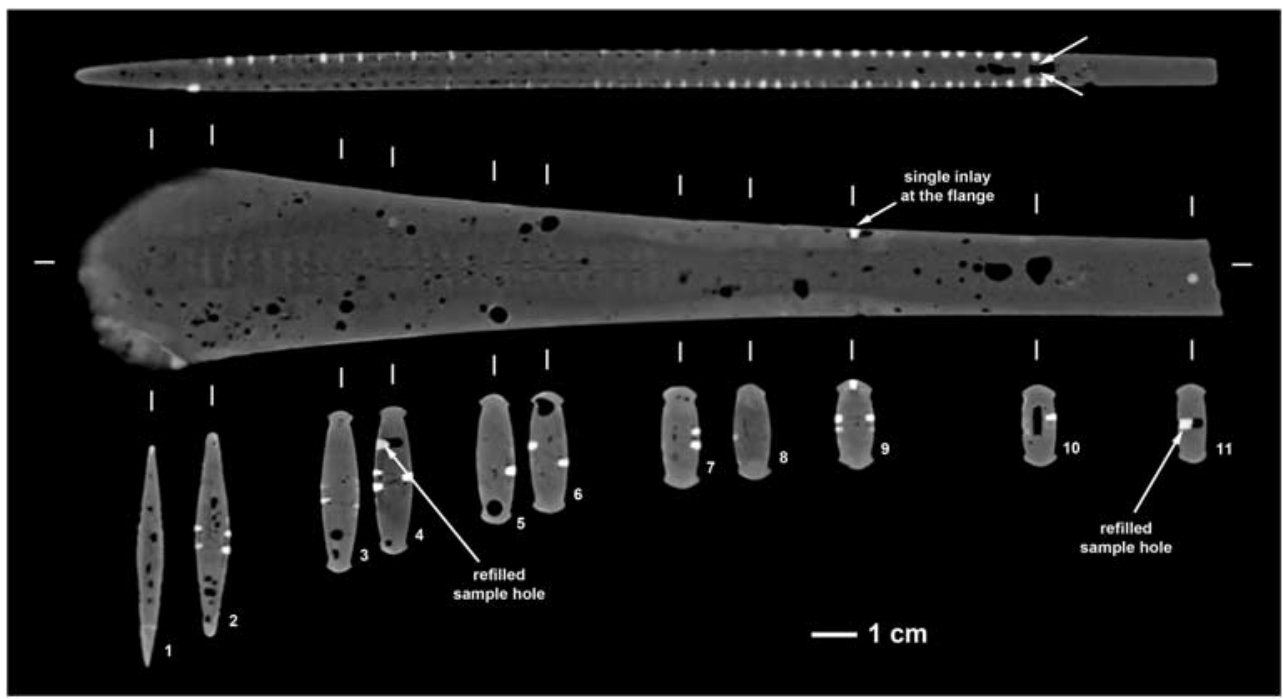

Fig I2. Virtual sections through neutron tomography images in all three directions, showing the numerous well-rounded gas inclusions, many of which are directly in contact with the copper inlays (arrowed) on the longitudinal section (at the top). The voids at the base of the electrum inlays, where they have not completely filled the pre-formed holes, are also well documented by this image. Image: Katja Hunger, Daniel Berger, Stefan Hartmann

(a)

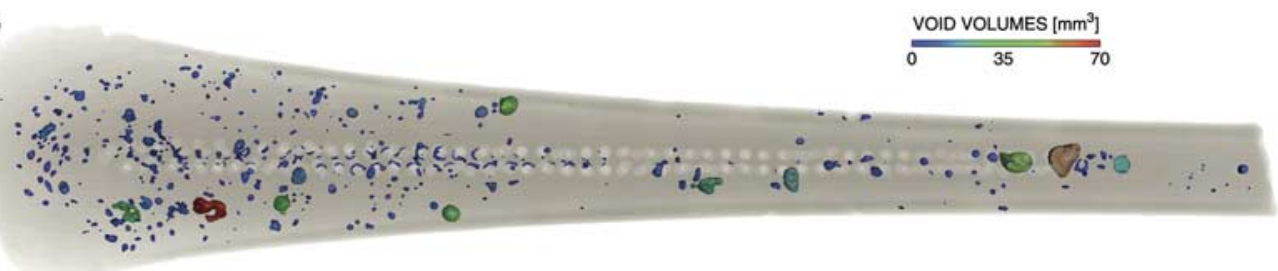

(b) $1 \mathrm{~cm}$ REL. INLAY VOLUMES [a.u.] $0.5 \quad 0.75 \quad 1.0$

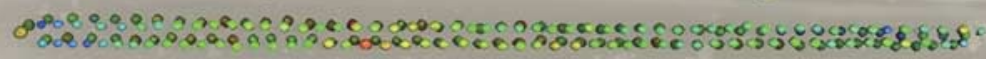

Fig I3. Neutron tomography reconstructions of the axe: (a) the relative volumes of the voids; (b) the electrum damascenings. Reconstruction: Stefan Hartmann

with the bronze base (Fig I2). This means that the copper cannot have been poured into the slots on the axe, since molten copper easily absorbs oxygen, subsequently releasing it whilst cooling, which normally causes high porosity in as-cast copper. Further evidence comes from the unfilled defects present at the bronze/copper interface (Fig I2.IO), for these 


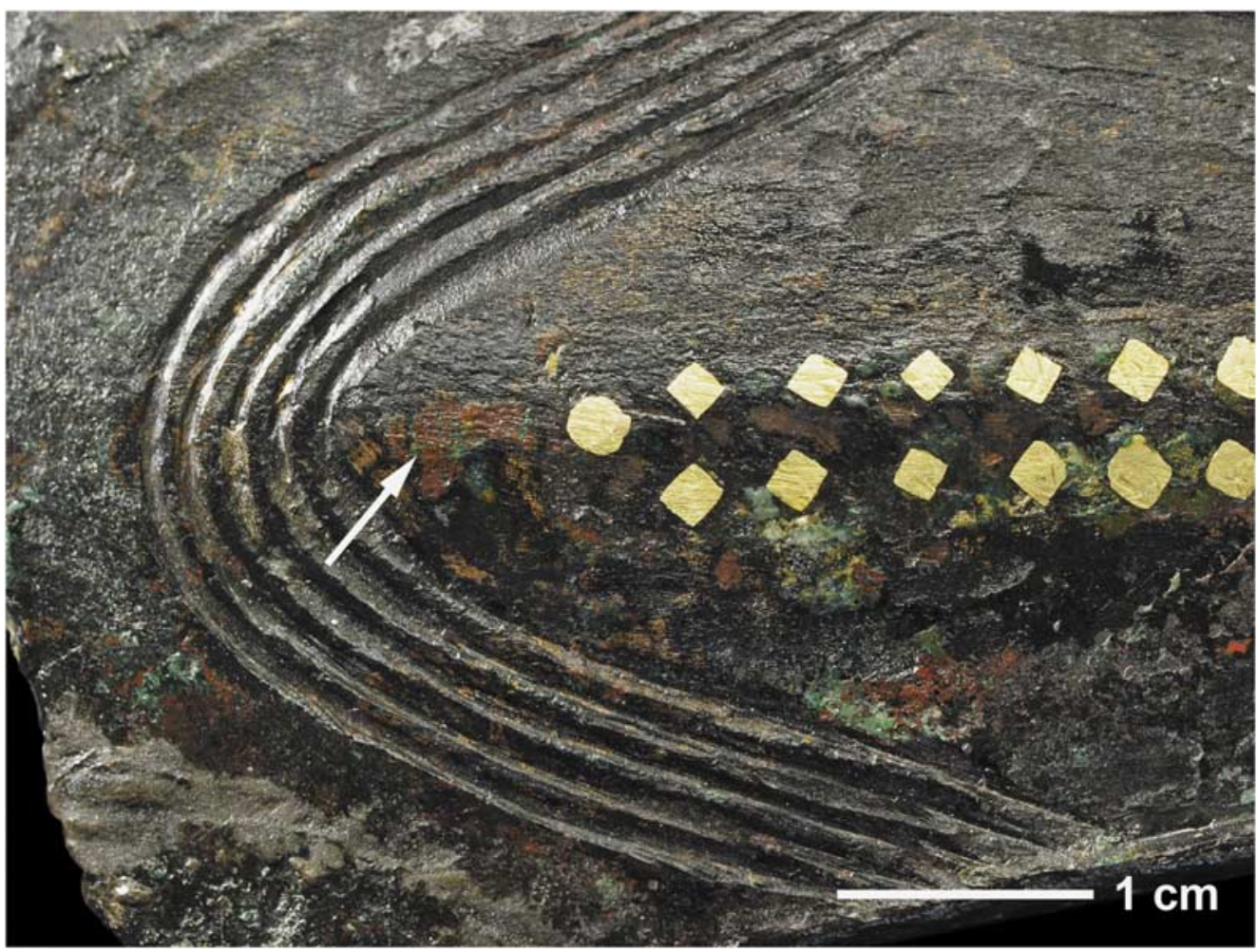

Fig I4. A detailed view of the inlay region showing one of the separate appendices that appear to have been added at both ends of the copper inlays. Photograph: Daniel Berger

would have been taken up by molten metal if the copper had been poured. It may therefore be concluded that forged and compacted copper strips were hammered into the slots, being wedged in securely only through plastic deformation and pressure against the boundaries. This procedure would have required prior annealing of the copper strips, otherwise they would have been too hard from forging to be inlaid. Since no further butt joints are discernible on either the neutron tomography images or the exposed surface, each strip was evidently put in as a single piece, rather than as a series of pieces. There are, however, unusual appendices at both ends of the strips that appear to have been set in separately (Fig I4). Possibly these small fillings were used to cover casting voids that were exposed to the surface of the bronze axe during casting. In this case they are not damascenings in the strict sense of a contrasting material, since they are primarily deployed for a technical function.

All the electrum rhombs were damascened into the copper base in much the same way. The relative consistency of the surface shape of the inlays suggests that all the recesses were formed using the same simple rhomb-shaped punch (see Fig 4). A bronze punch with a high tin content (around I4 per cent) would have been needed to make these almost $2 \mathrm{~mm}$-deep recesses in the copper strip. A punch with a lower tin content would have been too plastic and the tool would have needed frequent resharpening; the consistency of the rhomb shapes speaks for only slight resharpening. Given these observations, Tschumi's theory that the electrum rhombs were inserted into the copper 


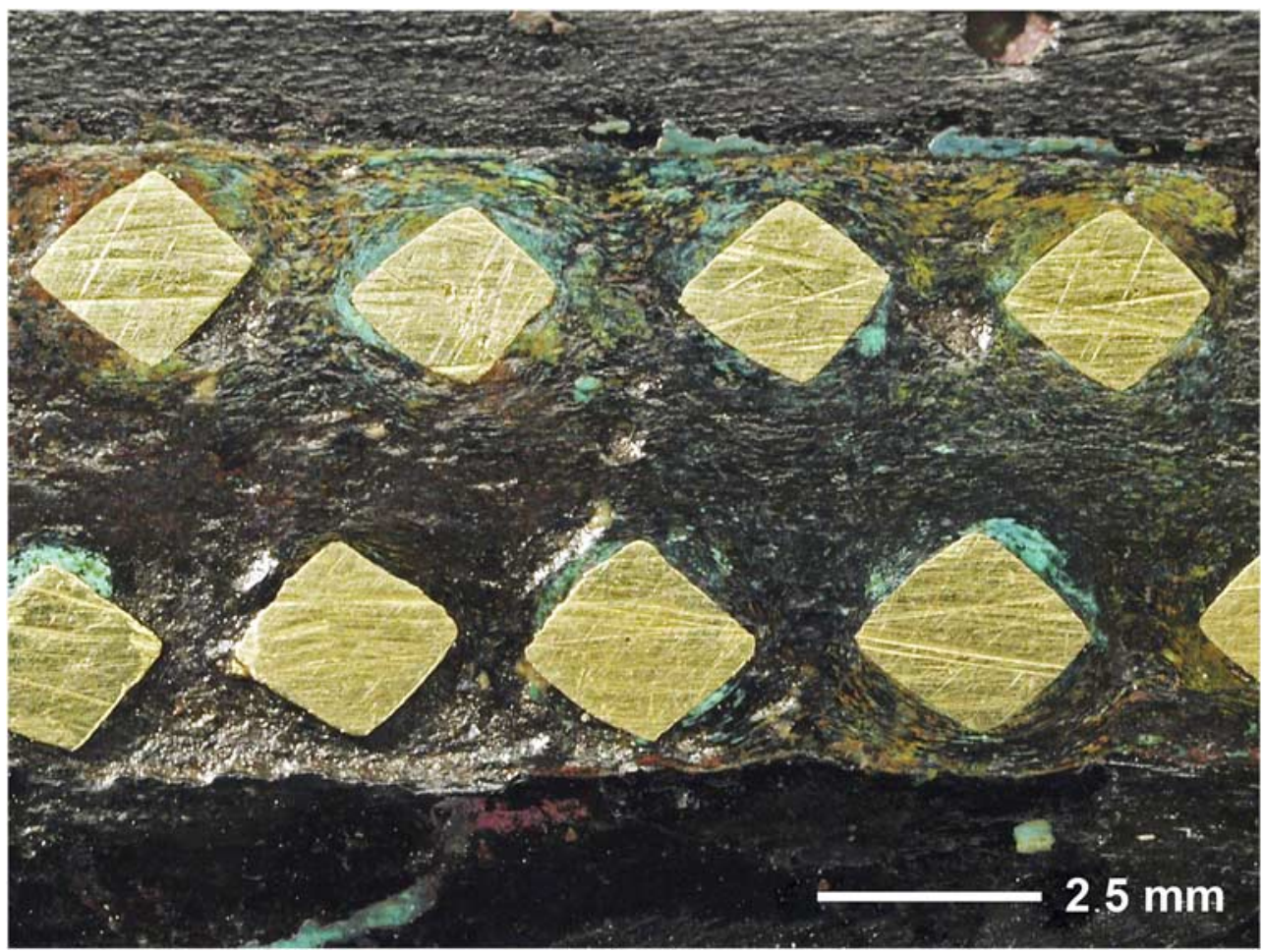

Fig I5. The different colours on the copper inlay result from corrosion products that have developed during burial; the ring-like form of the corrosion around the margins of the electrum damascenings reflects the way that the punching of the holes in the copper strips has deformed the microstructure. Photograph: Daniel Berger

strip first and then the composite whole hammered into the axe's body seems rather unlikely. ${ }^{49}$ Such a sequence would almost certainly have resulted in a far greater degree of variation in the rhomb shape than is the case.

The secondary damascening of the rhombs also helps to explain why there are no visible joint gaps between the copper inlays and the bronze. ${ }^{50}$ Gaps are typically present around bulky inlays, but in this case they would have been reduced or totally closed by the extensive punching involved in the inlaying of the electrum rhombs. One consequence of this manufacturing process is that the corrosion products that are present around the inlaid electrum appear to form rings (Fig I5), reflecting the way that the punching process has deformed the microstructure of the copper strips around each cavity.

Further support for our proposed manufacturing sequence comes from the form of the electrum inlays as revealed by neutron tomography (see Figs I 2 and I3a), where it can be seen that only some of the punched recesses, with their nearly straight sides, are completely filled with the precious metal. The remainder show large void spaces at their

49. Tschumi 1942 .

50. As far as can be assessed at the given spatial resolution with $250 \mu \mathrm{m}$. 
(a)

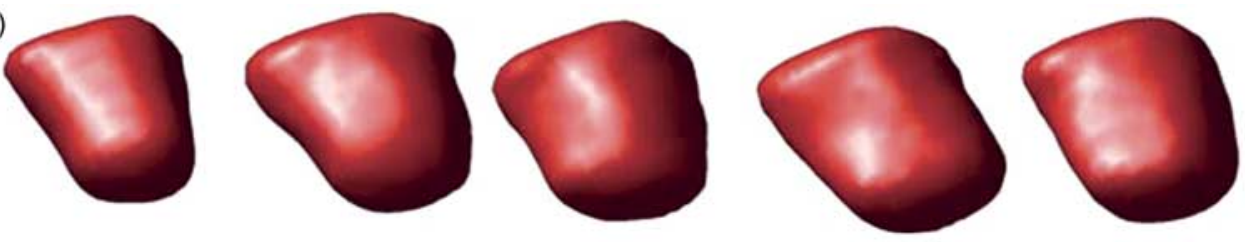

$1 \mathrm{~mm}$

(b)

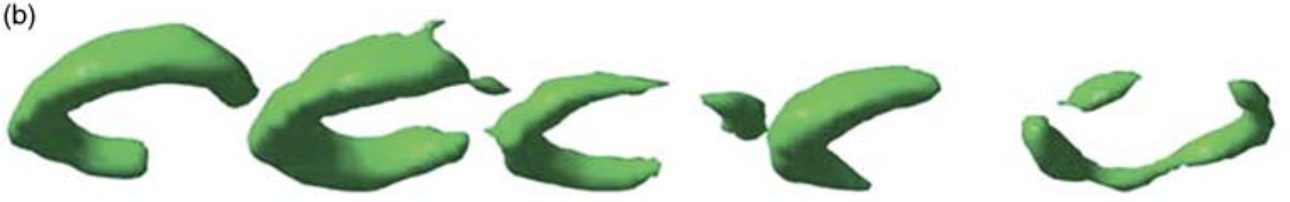

(c)
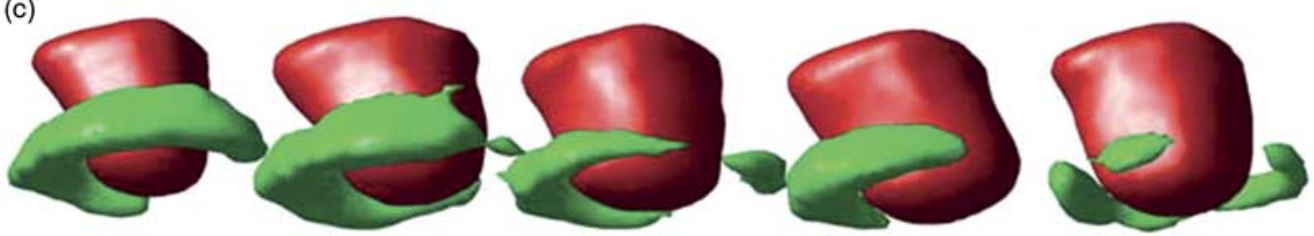

Fig I6. Volume rendering of a series of electrum inlays: (a) five neighbouring pieces; (b) the resulting void spaces on the bottoms of the recesses; (c) a composite of the two. The visualisation clearly shows that the electrum inlays tapered inwards from top to bottom. Image: Daniel Grolimund

bases; these are best visualised by volume rendering the tomography data (Fig I6). The electrum inlays themselves taper inwards, resulting in a sub-conical shape, and it is clear that these were not subjected to the kind of repeated hammering that would have filled the recesses entirely. Moreover, our data show that all the electrum inlays have nearly the same volume (Fig I3b) and were cut into approximately equal-sized pieces from an electrum rod with a round section prior to the damascening procedure.

\section{THE RESULTS FROM X-RAY DIFFRACTION ANALYSES}

As already mentioned, the application of synchrotron-based X-ray microdiffraction (micro-XRD) analysis in reflection mode is novel and there are still some problems with the technique; these are discussed in detail elsewhere. ${ }^{5 \mathrm{I}}$ It is sufficient here to note only that microdiffraction imaging of bulk objects under reflective conditions is particularly sensitive to surface roughness of the analysed area (which is clearly the case for the axe under study). In addition, the high (and thus very good) spatial resolution of the method results in a small diffracting volume, limiting the number of reflections to be used during phase assignment. Nevertheless, thousands of diffraction patterns were recorded on a regular two-dimensional grid pattern with high spatial resolution (low micrometre $(\mu \mathrm{m})$ scale). The area covered by this includes all three metal parts (Fig I7).

5I. Grolimund et al 2011, 1020-2. 

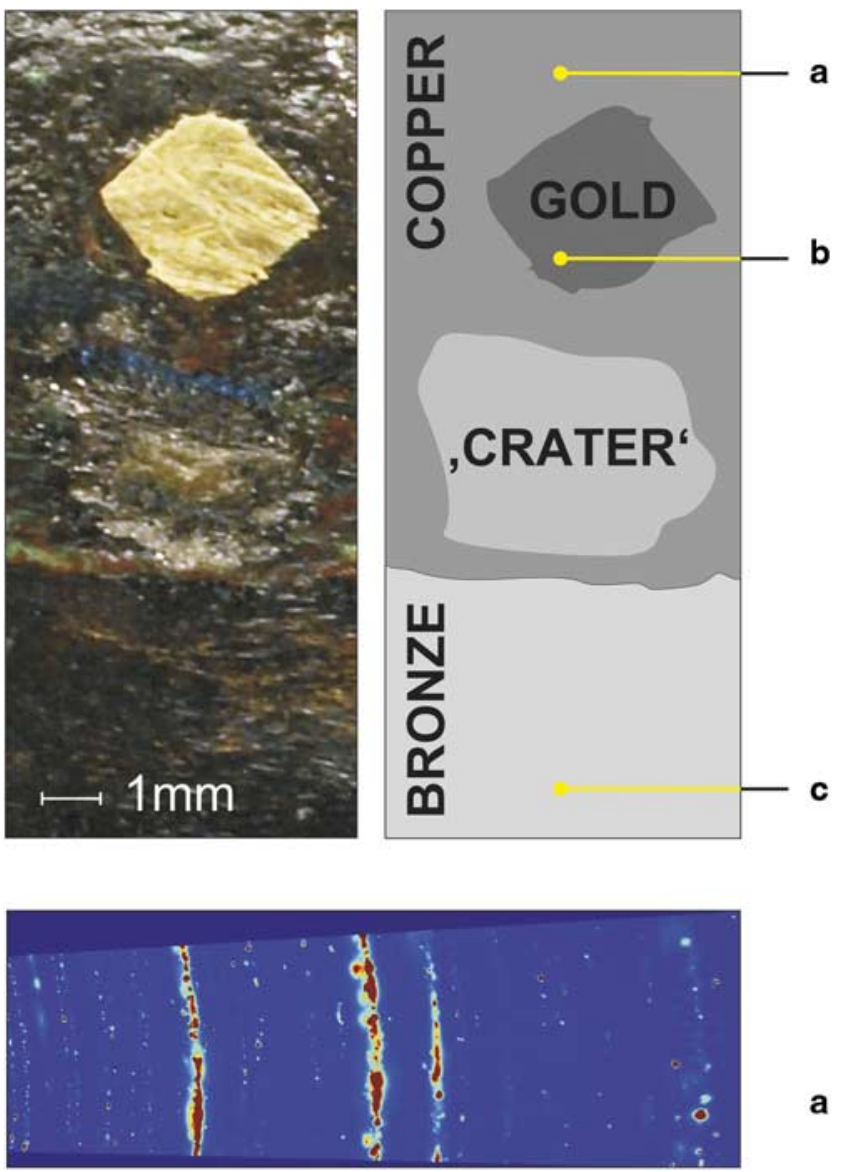

a

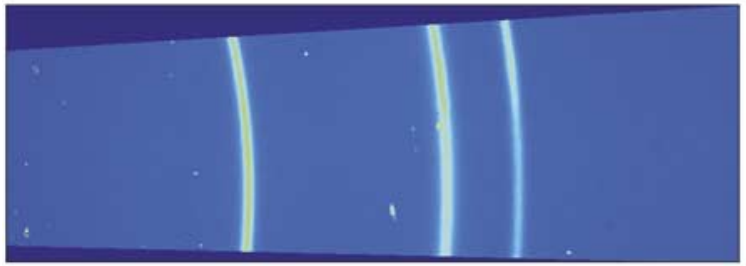

b

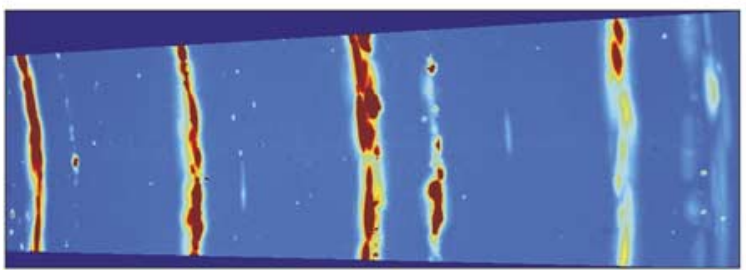

Fig I7. Spatially resolved microdiffraction imaging. The two top panels show a visible-light microscope image of the sample area alongside a schematic representation of the same area of the axe. The bottom panels show composite images of the diffraction pattern obtained by illuminating the copper inlay (a), the gold inlay (b) and the bronze body (c). Images: Daniel Grolimund 

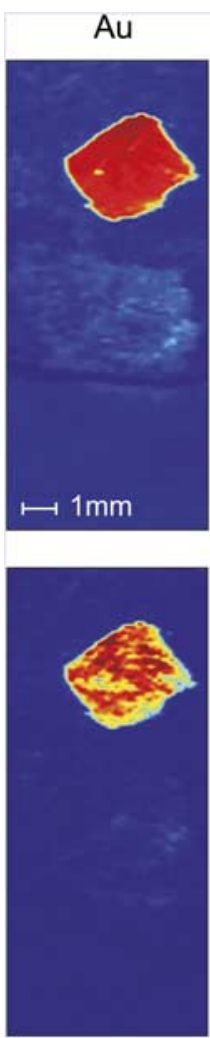

Gold

$\mathrm{Au}$
$\mathrm{Cu}$
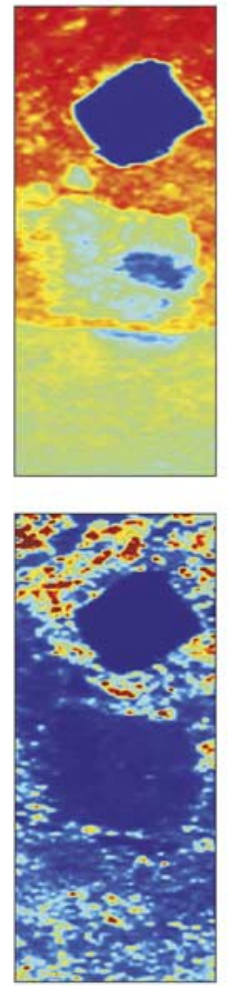

Cuprite

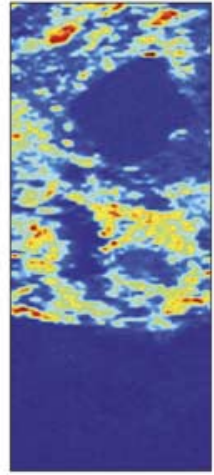

Malachite

$\mathrm{Cu}_{2} \mathrm{CO}_{3}(\mathrm{OH})_{2}$
$\mathrm{Sn}$
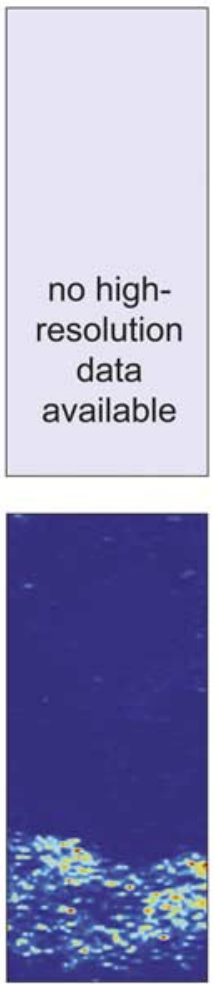

Bronze

$\mathrm{Cu}_{0.9} \mathrm{Sn}_{0.1}$

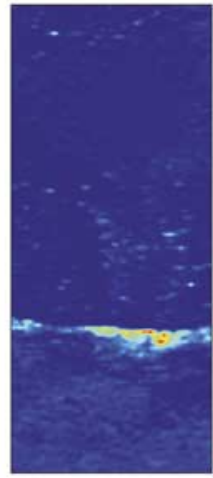

Cassiterite $\mathrm{SnO}_{2}$

Fig I8. The top row shows chemical distribution images of gold $(\mathrm{Au})$, copper $(\mathrm{Cu})$ and tin $(\mathrm{Sn})$, recorded by means of micro-XRF; the bottom row presents the spatial distribution of selected crystalline compounds determined by micro-XRD imaging.

Images: Daniel Grolimund

Summarised diffraction images (diffraction rings) are presented for each surface region (labelled $\mathrm{a}-\mathrm{c}$ ), from which it may be seen that the corrosion crust above the bronze base exhibits a very complex composition of crystalline phases. The ring pattern structures that originate from variably reflected X-rays are highly diagnostic for the mineral phases being formed, the reflection positions providing clear evidence for interpretation. With this it was possible to identify cuprous and stannic oxide (cuprite, $\mathrm{Cu}_{2} \mathrm{O}$; cassiterite, $\mathrm{SnO}_{2}$ ) as the main constituents of the bronze corrosion, associated with minor malachite (basic copper carbonate, not present in the area depicted in Fig I7) as well as some other phases that have not hitherto been recognised. Moreover, signals from the bronze metal itself are present. In contrast, stannic oxide and bronze are missing in the area of the copper inlay, thus providing additional support for the conclusion that tin is not present in this part of the damascening. Cuprite and malachite can, however, also be assigned to the diffraction patterns, which show that there is no fundamental difference in the corrosion layers of the two metal parts apart from quantitative variations (Fig I8). 
It is not possible, from these results, to identify whether any kind of deliberate colouring treatment was used on the object. The stannic oxide that was detected, as well as the other phases noted, all occur frequently on bronze and copper under normal burial conditions. ${ }^{52}$ However, one should bear in mind that not all the components have yet been identified and that only crystalline corrosion products can be detected with XRD. In order to track down possible X-ray amorphous components of the corrosion layer, additional studies, employing complementary analytical methods, such as Raman or infrared spectroscopy, are necessary. ${ }^{53}$

A further limitation of the diffraction analysis is that the patterns recorded on the rhombic inlays do not allow a precise conclusion about the true nature of the precious metal since gold, silver and electrum all yield the same peak systems with only slightly different peak positions. ${ }^{54}$ The observed shift towards higher diffraction angles during investigation compared with pure gold can therefore not be taken as evidence for the presence of a gold-silver alloy because it can also be the result of mechanical stress due to the cold-working procedure. This means we have to rely on the X-ray fluorescence measurements to specify the true nature of the golden inlays.

\section{CONCLUSIONS AND OUTLOOK}

This study has given us a new understanding of the methods of manufacture and decoration that were deployed to make one of the oldest damascened artefacts yet found north of the Alps. It has deduced that the object was cast either in a lost-wax casting mould or in a two-piece clay mould, which enabled the central slots to be cast (but whose cross sections could not, unfortunately, be revealed by neutron tomography). After a limited amount of post-cast working, the slots were inlaid with unalloyed copper strips using a hammering process. These strips were then punched almost 200 times in order to receive rhombic electrum inlays by means of a second mechanical operation (Fig I9). In a final stage, the resulting uneven surface was smoothed out by grinding and polishing, which is documented by multiple striations on the axe's surface (see Fig I5).

This kind of metal inlay decoration is a highly specialised form known as doubledamascening, best paralleled by Mycenaean and Levantine weapons from the Mediterranean region. However, apart from similarities in the damascening method the Swiss axe and the Mediterranean artefacts have little in common. Firstly, there are fundamental differences in the motifs used in the inlays: mainly complex figurative and floral designs on the Greek and Levantine objects (see Fig 8), compared with simple and geometrical motifs on the axe. In this respect, the axe decoration is much more like the round gold inlays of the Priziac dagger and the double-damascenings of the sword from Nantes (see Figs 6d and 7). Secondly, unalloyed copper is used as the immediate base for the precious-metal inlays in the case of the axe, contrasting with the use of copper-gold-alloy bases on the Mediterranean artefacts. These special copper alloys, with small amounts of gold $(<5 \mathrm{wt} \%)$ and sometimes silver and arsenic, too - often called corinthium aes or kyanos - are indeed of great interest to archaeologists as it is supposed

52. Scott 2002; Piccardo et al 2007; Ghoniem $201 \mathrm{I}$.

53. Berger 20I2b.

54. McKeehan 1922. 
(a)

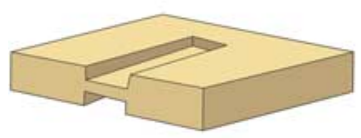

(d)

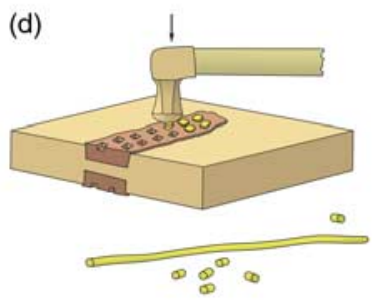

(f)

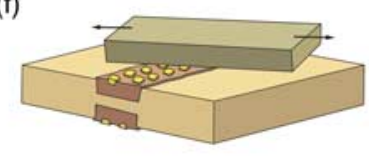

(b)

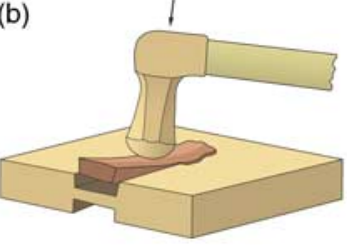

(c)

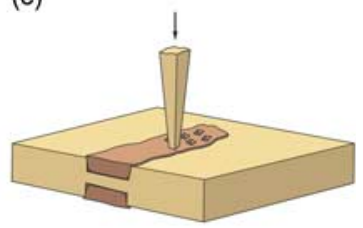

(e)

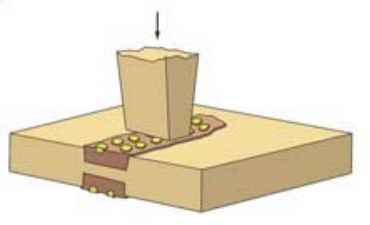

(g)

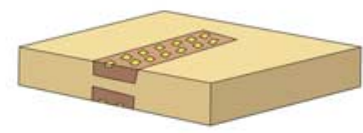

Fig I9. The Thun axe damascening process: (a) the axe body as cast and worked; (b) inlaying the copper strips with a hammer; (c) punching the recesses for the electrum inlays with a bronze punch; (d) inlaying the electrum pieces; (e) possible working with a flat punch; (f) grinding and polishing; (g) the finished axe. Drawing:

Daniel Berger

that they were produced intentionally for achieving dark blue, dark purple or even black patinas for contrasting purposes. ${ }^{55}$ If therefore the axe from Thun-Renzenbühl resulted from a transfer of Mediterranean technology, it would mean a crucial fabrication detail had been lost in the transfer process. Such a direction of transfer is anyway difficult to sustain on current knowledge, given the younger date of the Mycenaean pieces, and possibly of the Levantine ones too.

However, it is unlikely that the highly developed Mycenaean daggers suddenly occurred without precursors in the mid-seventeenth century BC. As early as 1930 Evans cited a dagger blade with incised (possibly chased) channels, but without inlays, from Psychro, on Crete, as a possible precursor of the famous Mycenaean daggers. ${ }^{56}$ Laffineur instead argues for local manufacturing on the Greek mainland by foreign craftsmen who looking at the technical similarities of the weapons noted above - most likely came from the Levantine coast. ${ }^{57}$ Yet this argument would lack any basis if the damascened objects from Greece and the Near East are in fact almost contemporaneous, as discussed by Jung. It might, in view of this, be worth reconsidering Strahm's suggestion that the prototypes of the Mycenaean daggers might be found further north, perhaps in the region of Romania, Bulgaria and Hungary; indeed, it is possible to speculate even further, and look to northwestern or central Europe. The metal-inlaying traditions on EBA daggers in Brittany

55. Giumlía-Mair and Craddock I993; Ogden I993; Giumlía-Mair and Riederer 1998.

56. Evans I930, III, III-I2.

57. Laffineur I991, 269-76. 
(especially Priziac) and southern Britain, along with a series of inlaid and plated objects on non-metallic bases, ${ }^{58}$ illustrate an early knowledge of material combination procedures for bi- or polychromatic purposes in this region reaching back to the nineteenth/eighteenth century BC.

In addition, other metal combination techniques can be seen, for instance, on two fullhilted daggers of Alpine type that have been excavated from burials in Bois-de-Vaux, Lausanne, in Vaud canton, Switzerland. The tangs of these daggers have alternating discs of copper and tin bronze and are therefore comparable - albeit not technologically - to damascened objects. ${ }^{59}$ The Alpine dagger type in turn takes us back to Thun-Renzenbühl grave no. I, which also yielded a dagger of this special type, but partially decorated with (now decayed) discs of organic material (bone, wood or antler) instead of metal (see Fig I). Despite the difference in the materials used, the effect of contrasting bands of colour would have been similar.

All things considered, it is possible to suggest that the damascene technique used on the Thun axe is based on indigenous metal-inlaying traditions that developed north of the Alps and that this axe could itself have served as the prototype for later damascened objects in other regions. Nor can we entirely exclude the possibility that the doubledamascening technique originated here and found its way to south-eastern Europe, where it was brought to a high technical and artistic level in the Mycenaean period. Such a tempting scenario is, of course, not imaginable without intermediate stages but there is at present only one damascened artefact from the region in between: a gold pendant or amulet from Târgu Mureș, Romania, that possessed silver damascenings. Its dating to the first half of the second millennium $\mathrm{BC}$ is, however, rather insecure and it is therefore hardly suitable for supporting the theory. ${ }^{60}$

For this reason the only factors that could possibly connect the axe with south-eastern Europe is the curved ornament on the one hand ${ }^{61}$ and the composition of the electrum inlays on the other. According to the metal analyses carried out here, these were all made from the same gold ore with up to 30 per cent silver content. Natural gold deposits of this kind are typical of the Carpathians (Siebenbürgen), as Hartmann has pointed out, ${ }^{62}$ but since Schmiderer has recently identified gold ores in the eastern Alps and in Bohemia that also reach such a high silver content, these regions must also be accounted for. In order to assign the electrum inlays on the axe to a specific ore district it might therefore in future be necessary to measure trace elements, such as bismuth, tellurium or platinum group metals (platinum, palladium, ruthenium), as they seem to be diagnostic. ${ }^{63}$ Copper and tin, which are both present in the electrum, are not sensitive enough to be used as an indicator of provenance since they could have been introduced by accidental alloying or from a secondary gold deposit (known in geology as a placer deposit) containing copper and tin. Only the percentage of silver, therefore, is of value to this discussion, and this is far too weak to serve as a basis for establishing trade connections with eastern or

58. Apart from daggers there is a large corpus of objects that have metal inlays or platings on nonmetallic bases: eg, Eluère 1982, figs 26, 4I-9; Clarke et al I985, figs 4.29-32, 4.39-40, 4.54-56, $4.59,5.28,5.49$. A very rare example of a dagger where tin nails were used as inlays in horn comes from Bargeroosterveld, The Netherlands: see Clarke et al 1985, 226-7.

59. Schwenzer 2004, nos 286 and 287; Berger 20I2a, fig I3.

60. Kovács and Raczky 1999, 6I, fig 25; Kemenczei 2005, 6I-2.

61. Cf Strahm 1972, I05-7.

62. Hartmann I970, 39-42.

63. Schmiderer 2009, II, 2I, 92, 95, I03-4. 
south-eastern European cultures or technology transfer. More sensitive analysing methods are thus needed if we are to make further progress.

Neither is it currently possible to compare the Thun-Renzenbühl axe with the Mediterranean artefacts entirely on the basis of inlaying technology, partly because only a few of the latter objects have been investigated to the same level of detail. ${ }^{64}$ More research with high-resolution imaging methods (such as neutron microtomography) is necessary to obtain further information that could be helpful in understanding any possible technological and stylistic relationships. Those relationships are, however, better understood in the case of the axe and the four damascened sword blades from north of the Alps (see Fig 6). ${ }^{65}$ Like the Thun axe, all four have narrow slots that were made when the blades were cast in their clay moulds, into which unalloyed copper damascenings were subsequently hammered. The slots are almost rectangular in cross section, as is also assumed to be the case for the axe (although this could not be confirmed because of the imaging limitations already mentioned). The swords are of considerably later date, but none of the evidence contradicts the possibility that the damascening tradition was handed down in this region for several centuries. This is especially comprehensible for the sword from Nantes, which has the same kind of double-damascening as on the axe from Thun-Renzenbühl and almost the same V-shaped copper bands as on the sword blades from Nebra and Vreta Kloster.

On the other hand, the Nebra Sky Disk, although nearly contemporaneous with the axe, is not comparable with any other of the other damascened artefacts in technology and style. Instead, it was made by the 'Tauschier-Plattierung' technique, a combination of damascening and plating in which only the edges of the electrum foils are fixed to the metal base. In this case, undercut grooves were first chased into the fairly soft tin bronze of the disk, ${ }^{66}$ resulting in slightly raised rims round the outer edges of the channels (Fig 20a-b). Having no direct relationship with any of the other damascened objects, whether from north or south of the Alps, this special inlay technique can best be paralleled by plated objects of early date. ${ }^{67}$ Essentially, the Sky Disk remains unique, especially in its iconography, though it exhibits the same desire for colour contrast that we find on such damascened objects as the Swiss axe.

The porous structure of the axe and its spoon-like shape and slim body make it very unlikely that it was intended to be used as a tool, and the rare metal-inlay decoration makes it even less likely that it had a utilitarian purpose. Thus we tend to agree with Hundt that the axe probably served as a weapon and as a status symbol for its owner. ${ }^{68}$ In this context, the already high aesthetic value could have been enhanced by artificial colouring treatment to point up the contrasting metals, as is known to have been the case with the damascened finds from Greece. We found no unambiguous traces of such treatment in the case of the axe, but it is absolutely possible to achieve strong colour contrasts between bronze and copper under the conditions that we have outlined for its manufacture, even without precious-metal alloying. ${ }^{69}$ Finding evidence for this remains one of our objectives for future research into this fascinating object.

64. Giumlía-Mair 2012.

65. Berger 2012a.

66. The copper base metal of the Sky Disk contains $2.6 \mathrm{wt} \%$ tin and some impurities: see Pernicka 2010.

67. Needham et al 20I0, fig I2.

68. Hundt 1973, 2 IO.

69. Berger 20I2a, fig I24. 
(a)

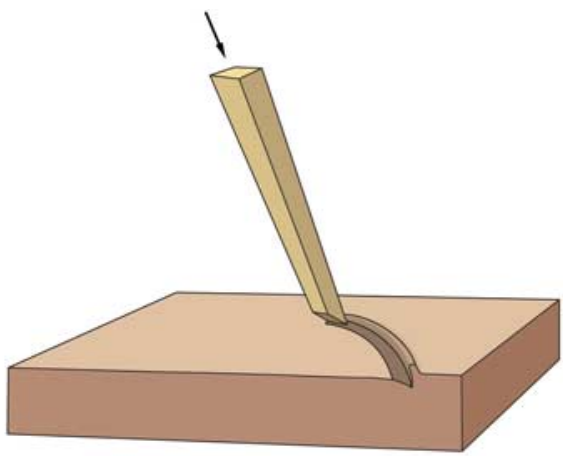

(c)

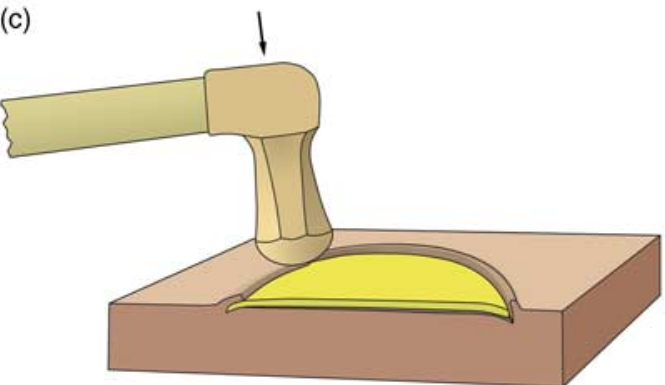

(b)

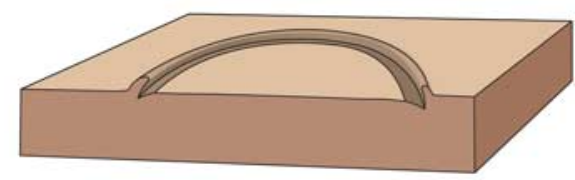

(d)

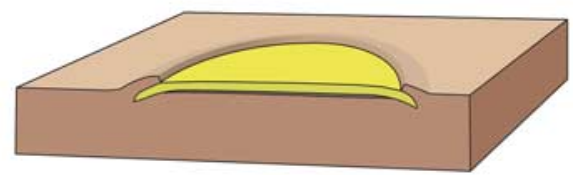

Fig 20. The damascene procedure used on the Nebra Sky Disk: (a) chasing the groove for the electrum foil into the low-tin bronze base $(2.6 \mathrm{wt} \% \mathrm{tin})$; (b) the resulting rim of the completed groove is slightly upraised; (c) forging the rim over the inlaid electrum foil; (d) the foil is clamped securely in the finished work. Drawing: Daniel Berger

\section{ACKNOWLEDGEMENTS}

This paper was first presented at the Archaeometallurgy in Europe III symposium, held at the Deutsche Bergbau-Museum Bochum from 29 June to I July 20II. The authors are very grateful to the Historical Museum, Bern, and the Swiss National Museum, Zurich, for allowing us to study the artefact in detail and for their financial and organisational support. We are also grateful to $\mathrm{C}$ Borca and $\mathrm{H}$ A O Wang for help in evaluating the data from the X-ray fluorescence and diffraction analyses and to Stuart Needham, FSA, for his critical reading of the manuscript and his suggested revisions.

\section{BIBLIOGRAPHY}

Berger, D 20I2a. Bronzezeitliche Färbetechniken an Metallobjekten nördlich der Alpen: Eine archäometallurgische Studie zur prähistorischen Anwendung von Tauschierung und Patinierung anhand von Artefakten und Experimenten, Forschungsberichte des Landesmuseums für Vorgeschichte Halle 2,
Halle (Saale): Landesamt für Denkmalpflege und Archäologie Sachsen-Anhalt Landesmuseum für Vorgeschichte Halle

Berger, D 20I2b. 'Schwarz auf gelb - Untersuchungen zur künstlichen Korrosion prähistorischer Metallgegenstände am Beispiel eines spätbronzezeitlichen Lappenbeiles in 
der Sammlung des Berliner Museums für Vor- und Frühgeschichte', Acta Praehistorica et Archaeologica, 44, 59-77

Berger, D forthcoming. 'Zur Technologie frühbronzezeitlicher Tauschierarbeiten nördlich der Alpen mit besonderer Berücksichtigung des Schwertes aus den "Marais de Nantes", eTopoi - Fournal of Ancient Studies, 2

Berger, D, Schwab, R and Wunderlich, C-H 2010. 'Technologische Untersuchungen zu bronzezeitlichen Metallziertechniken nördlich der Alpen vor dem Hintergrund des Hortfundes von Nebra', in Meller and Bertemes 20I0, 75I-78

Billig, G 1957. 'Das Prunkbeil von Schweta. Ein Beitrag zur Herstellungstechnik und zum Verwendungszweck der frühbronzezeitlichen Randbeile in Mitteldeutschland', Arbeitsund Forschungsberichte zur Sächsischen Bodendenkmalpflege, 6, 285-316

Briard, J 1984. Les tumulus d'Armorique (L'âge du Bronze en France 3), Paris: Picard

Clarke, D V, Cowie, T G and Foxon, A 1985. Symbols of Power at the Time of Stonehenge, Edinburgh: National Museum of Antiquities of Scotland

David-Elbiali, M 2000. La Suisse occidentale au IIe millénaire av $\mathcal{f}$-C: chronologie, culture, intégration européenne, Cahiers d'archéologie romande 80, Lausanne

David-Elbiali, M and Hafner, A 2010. 'Gräber, Horte und Pfahlbauten zwischen Jura und Alpen. Die Entwicklung elitärer sozialer Strukturen in der frühen Bronzezeit der Westschweiz', in Meller and Bertemes 2010, 2I $7-38$

Ehser, A, Borg, G and Pernicka, E 20II. 'Provenance of the gold of the Early Bronze Age Nebra Sky Disk, central Germany: geochemical characterization of natural gold from Cornwall', European $\mathcal{F}$ Mineralogy, 23 (6), 895-910

Eluère, C 1982. Les ors préhistoriques (L'âge du Bronze en France 2), Paris: Picard

Evans, A 1930. The Palace of Minos: a comparative account of the successive stages of the early Cretan civilisation as illustrated by the discoveries at Knossos, 4 vols, London: Macmillan

Flatt, R and Huber, K I942. 'Über moderne Hilfsmittel zur Untersuchung antiker Metalle', fahrbuch des Bernischen Historischen Museums in Bern, 2I, 49-52

Gerloff, S 1975. The Early Bronze Age Daggers in Great Britain and a Reconsideration of the Wessex Culture, Prähistorische Bronzefunde VI.2, Munich: C H Beck'sche
Ghoniem, M 20II. 'The characterization of a corroded Egyptian bronze statue and study of the degredation phenomena', Int $\mathcal{F}$ Conserv Sci, 2 (2), 95-I08

Giumlía-Mair, A 1996. 'Das Sichelschwert von Balâta-Sichem: Prunkwaffe der Staatlichen Sammlung ägyptischer Kunst München metallurgisch untersucht', Antike Welt, 27 (4), 340

Giumlía-Mair, A 2012. 'The Enkomi cup: niello versus kuwano', in Eastern Mediterranean Metallurgy and Metalwork in the Second Millenium BC: a conference in honour of fames D Muhly, Nicosia, IO-II October 2009 (eds V Kassianidou and G Papasavvas), I07-I6, Oxford: Oxbow Books

Giumlía-Mair, A and Craddock, P T 1993. Das schwarze Gold der Alchemisten: Corinthium aes, Zaberns Bildbände zur Archäologie II, Mainz: Philipp von Zabern

Giumlía-Mair, A and Riederer, J 1998. 'Das tauschierte Krummschwert in der Ägyptischen Sammlung München', Berliner Beiträge zur Archäometrie, 15, 9I-4

Grolimund, D, Berger, D, Bolliger-Schreyer, S, Borca, C N, Hartmann, S, Müller, F, Hovind, J, Hunger, K, Lehmann, E H, Vontobel, $\mathrm{P}$ and Wang, $\mathrm{H}$ A $\mathrm{O}$ 20II. 'Combined neutron and synchrotron X-ray microprobe analysis: attempt to disclose 3600 years-old secrets of a unique Bronze Age Metal artifact', $\mathcal{f}$ Analytical Atomic Spectrometry, 26 (5), IOI2-23

Hartmann, A 1970. Prähistorische Goldfunde aus Europa: Spektralanalytische Untersuchungen und deren Auswertung, Studien $\mathrm{zu}$ den Anfängen der Metallurgie 3, Berlin: Gebr. Mann

Hartmann, A 1982. Prähistorische Goldfunde aus Europa II: Spektralanalytische Untersuchungen und deren Auswertung, Studien $\mathrm{zu}$ den Anfängen der Metallurgie 5, Berlin: Gebr. Mann

Hundt, H-J I973. Book review of B-U Abels, Die Randleistenbeile in Baden-Württemberg, dem Elsass, der Franche Comté und der Schweiz, Jahrbuch des Römisch-Germanischen Zentralmuseums, 20, 203-II

Jung, R 2010. 'Der Charakter der Nordkontakte der minoischen und mykenischen Zivilisation um I6 v. u. Z.', in Meller and Bertemes 2010, 657-74

Junghans, S, Sangmeister, E and Schröder, M 1968. Kupfer und Bronze in der frühen Metallzeit Europas: Die Materialgruppen beim Stand von I2000 Analysen, Studien zu den 
Anfängen der Metallurgie 2, Berlin: Gebr. Mann

Keller, F I844. 'Waffen und Geräthschaften aus der Sammlung des Herren Alt-Landamman Lohner in Thun', Mitteilungen der Antiquarischen Gesellschaft in Zürich, 2 (7), I7-25

Kemenczei, T 2005. Funde ostkarpatenländischen Typs im Karpatenbecken, Prähistorische Bronzefunde XX.Io, Stuttgart: Franz Steiner

Kerner, M 2007. 'Das Randleistenbeil von Thun-Renzenbühl als Venus-Kalender', Géomatique Suisse, 8, 392-6

Kibbert, K I980. Die Äxte und Beile im mittleren Westdeutschland, Prähistorische Bronzefunde IX.Io, Munich: C H Beck'sche

Kovács, T and Raczky, P 1999. Prähistorische Goldschätze aus dem Ungarischen Nationalmuseum: Ausstellung im Museum für Vor- und Frühgeschichte, Archäologisches Museum, Frankfurt am Main, I6.10.1999-9.I.2000, Budapest: Ungarisches Nationalmuseum

Laffineur, R I99I. 'Material and craftsmanship in the Mycenae shaft graves: imports vs local production', Minos, 25 (6), 245-95

Lohner, C F L I832. 'Fundbericht', Der schweizerische Geschichtsforscher, 8, 440

McKeehan, LW I922. 'The crystal structure of silver-palladium and silver-gold alloys', Physical Rev, 20 (5), 424-32

Meller, H 2002. 'Die Himmelsscheibe von Nebra: Ein frühbronzezeitlicher Fund von außergewöhnlicher Bedeutung', Archäologie in Sachsen-Anhalt, $\mathbf{1}, 7-20$

Meller, H 2004. 'Die Himmelsscheibe von Nebra', in Der geschmiedete Himmel: Die weite Welt im Herzen Europas vor 3600 fahren (ed H Meller), 22-3I, Stuttgart: Theiss

Meller, H 20IO. 'Nebra: Vom Logos zum Mythos: Biographie eines Himmelsbildes', in Meller and Bertemes 2010, 23-76

Meller, H and Bertemes, F (eds) 20Io. Der Griff nach den Sternen: Wie Europas Eliten zu Macht und Reichtum kamen. Internationales Symposium in Halle (Saale), I6.-2I. Februar 2005, Tagungen des Landesmuseums für Vorgeschichte Halle, 5, Halle (Saale): Landesamt für Denkmalpflege und Archäologie Sachsen-Anhalt - Landesmuseum für Vorgeschichte Halle

Needham, S, Lawson, A J and Woodward, A 2010. 'A noble group of barrows: Bush Barrow and the Normanton Down Early Bronze Age cemetery two centuries on', Antiq F, 90, I-39

Ogden, J I993. 'Aesthetic and technical considerations regarding the colour and texture of ancient goldwork', in Metal Plating and Patination: cultural, technical and historical developments (eds S La Niece and $\mathrm{P}$ T Craddock), 39-49, Oxford: Butterworth-Heinemann

Pernicka, E 20I0. 'Archäometallurgische Untersuchungen am und zum Hortfund von Nebra', in Meller and Bertemes 2010, 719-34

Piccardo, P, Mille, B and Robbiola, L 2007. 'Tin and copper oxides in corroded archaeological bronzes', in Corrosion of Metallic Heritage Artefacts: investigation, conservation and prediction of long term behaviour (eds P Dillmann, P Piccardo, $\mathrm{H}$ Matthiesen and G Beranger), 219-38, European Federation of Corrosion Publications 48, Boca Raton, Fla: CRC Press

Reinecke, P I902. 'Zu neueren Funden aus dem Südosten', Wiener Prähistorische Zeitschrift, 29, 9I-I05

Schauer, P I984. 'Spuren minoisch-mykenischen und orientalischen Einflusses im atlantischen Westeuropa', Fahrbuch des Römisch-Germanischen Zentralmuseums, 3I, I37-86

Schickler, H 1974. Book review of B Hänsel, Beiträge zur Chronologie der mittleren Bronzezeit im Karpatenbecken, Fundberichte aus Baden-Württemberg, I, 705-34

Schmiderer, A 2009. 'Geochemische Charakterisierung von Goldvorkommen in Europa', unpublished doctoral thesis, University of Halle-Wittenberg, Spielberg

Schwab, R, Ullén, I and Wunderlich, C-H 2010. 'A sword from Vreta Kloster, and black patinated bronze in Early Bronze Age Europe', J Nordic Archaeol Sci, 17, 27-35

Schwenzer, S 2004. Frühbronzezeitliche Vollgriffdolche: Typologische, chronologische und technische Studien auf der Grundlage einer Materialaufnahme von Hans-fürgen Hundt, Kataloge vor- und frühgeschichtlicher Altertümer 36, Mainz: Römisch-Germanisches Zentralmuseum

Scott, D A 2002. Copper and Bronze in Art: corrosion, colorants, conservation, Los Angeles, Calif: Getty Conservation Institute

Strahm, C 1968. 'Renzenbühl und Ringoldswil: Die Fundgeschichte zweier frühbronzezeitlicher Komplexe', fahrbuch des Bernischen Historischen Museums in Bern, 45 (4), 32 I-7I

Strahm, C 1972. 'Das Beil von ThunRenzenbühl', Helvetia Archaeologica, 3, 99-II2

Tschumi, O I942. 'Von den Anfängen des Tauschierungsverfahrens', fahrbuch des 
Bermischen Historischen Museums in Bern, 21, 46-8

Wiltshire Heritage Museum 2008. Insignia of Dignity: gold at Stonehenge, exhibition guide, Devizes: Wiltshire Heritage Museum

Wirth, M 2003. Rekonstruktion bronzezeitlicher Gießereitechniken mittels numerischer Simulation, gießtechnologischer Experimente und werkstofftechnischer Untersuchungen an Nachguss und Original, Gießerei-Institut 40, Aachen

Wunderlich, C-H 2005. 'Die Tauschiertechnik der Funde von Nebra vor dem Hintergrund

\section{RÉSUMÉ}

Le damasquinage, défini dans ce contexte comme étant un enchâssement de métal dans une base faite d'un métal différent, est une technique décorative rare au début de l'âge de bronze, connue seulement grâce à sept objets en bronze trouvés dans le Nord des Alpes. Cet article relate le premier examen scientifique approfondi d'une découverte de ce type, la hache de la tombe $\mathrm{n}^{\circ} 1$ de Thun-Renzenbühl. Ce projet interdisciplinaire, auquel participent plusieurs établissements allemands et suisses, a étudié cette hache au moyen de l'imagerie neutronique et de la microsonde de Castaing, complétées par un examen au microscope. Il en a résulté une tentative de reconstituer la fabrication et la décoration, ainsi qu'un réexamen de la question énigmatique portant sur les origines de la technique du damasquinage dans le Nord des Alpes.
"Mykenischer" Einlegearbeiten', in Der Griff nach den Sternen. Wie Europas Eliten zu Macht und Reichtum kamen. Internationales Symposium in Halle (Saale), I6.-2I. Februar 2005, Abstractband zur Tagung, 79-8I, Halle (Saale): Landesamt für Denkmalpflege und Archäologie Sachsen-Anhalt Landesmuseum für Vorgeschichte Halle

Xenaki-Sakellariou, A and Chatziliou, C 1989. Peinture en métal á l'époque mycénienne: incrustation damasquinage niellure, Athens: Ekdotike Athenon

\section{ZUSAMMENFASSUNG}

Tauschierungen, d. h. Metallein- oder -auflagen an Metall, sind an frühbronzezeitlichen Metallobjekten im Gebiet nördlich der Alpen ausgesprochen seltene Verzierungselemente. Insgesamt sind nur sieben Funde mit Metalleinlagen bekannt, die zu rein ästhetischen Zwecken angebracht wurden. Im Rahmen eines interdisziplinären Forschungsprojektes zwischen verschiedenen Institutionen bestand 2010 die Möglichkeit, mit dem berühmten Beil aus Thun-Renzenbühl eines der seltenen Objekte sowohl mittels Neutronenradiografie, Röntgenfluoreszenzspektrometrie und Röntgendiffraktometrie als auch optische Mikroskopie eingehend zu untersuchen. Der Beitrag stellt die Ergebnisse der Studie mit dem vorrangigen Ziel vor, die Herstellungs- und Verzierungstechnik des Fundes zu rekonstruieren. Damit sollen Anhaltspunkte für die Herkunft der Tauschiertechnik gefunden werden, die für die Artefakte nördlich der Alpen bislang noch weitgehend ungeklärt ist. 